\title{
Exploring the role of fire, succession, climate, and weather on landscape dynamics using comparative modeling ${ }^{\text {th }}$
}

\author{
Robert E. Keane ${ }^{\mathrm{a}, *}$, Geoffrey J. Cary ${ }^{\mathrm{b}, \mathrm{c}}$, Mike D. Flannigan ${ }^{\mathrm{d}, \mathrm{e}}$, Russell A. Parsons ${ }^{\mathrm{a}}$, \\ Ian D. Davies ${ }^{\mathrm{b}}$, Karen J. King ${ }^{\mathrm{b}}$, Chao Li $^{\mathrm{f}}$, Ross A. Bradstock ${ }^{\mathrm{g}, \mathrm{c}}$, Malcolm Gill ${ }^{\mathrm{b}, \mathrm{c}}$ \\ a USDA Forest Service, Rocky Mountain Research Station, Missoula Fire Sciences Laboratory, 5775 Highway 10 West, Missoula MT 59808, USA \\ b The Fenner School of Environment and Society, Australian National University, Canberra, Australia \\ ${ }^{\mathrm{c}}$ Bushfire Cooperative Research Centre, East Melbourne, Australia \\ ${ }^{\mathrm{d}}$ Canadian Forest Service, Sault Ste Marie ON, Canada \\ e Dept Renewable Resources, University of Alberta, Edmonton, AB, Canada \\ ${ }^{\mathrm{f}}$ Canadian Forest Service, Edmonton, Alberta, Canada \\ ${ }^{g}$ Department of Environment and Conservation, (NSW), Hurstville, NSW, Australia
}

\section{A R T I C L E I N F O}

\section{Article history:}

Received 13 March 2013

Received in revised form 13 June 2013

Accepted 17 June 2013

\section{Keywords:}

Simulation modeling

Model comparison

Succession

Landscape dynamics

Landscape ecology

Wildland fire

\begin{abstract}
A B S T R A C T
An assessment of the relative importance of vegetation change and disturbance as agents of landscape change under current and future climates would (1) provide insight into the controls of landscape dynamics, (2) help inform the design and development of coarse scale spatially explicit ecosystem models such as Dynamic Global Vegetation Models (DGVMs), and (3) guide future land management and planning. However, quantification of landscape change from vegetation development and disturbance effects is difficult because of the large space and long time scales involved. Comparative simulation modeling experiments, using a suite of models to simulate a set of scenarios, can provide a platform for investigating landscape change over more ecologically appropriate time and space scales that control vegetation and disturbance. We implemented a multifactorial simulation experiment using five landscape fire succession models to explore the role of fire and vegetation development under various climates on a neutral landscape. The simulation experiment had four factors with two or three treatments each: (1) fire (fire and no fire), (2) succession (dynamic and static succession), (3) climate (historical, warm-wet, warmdry), and (4) weather (constant, variable). We found that, under historical climates, succession changed more area annually than fire by factors of 1.2 to 34 , but one model simulated more landscape change from fire (factor of 0.1 ). However, we also found that fire becomes more important in warmer future climates with factors decreasing to below zero for most models. We also found that there were few differences in simulation results between weather scenarios with low or high variability. Results from this study show that there will be a shift from vegetation processes that control today's landscape dynamics to fire processes under future warmer and drier climates, and this shift means that detailed representations of both succession and fire should be incorporated into models to realistically simulate interactions between disturbance and vegetation.
\end{abstract}

Published by Elsevier B.V.

\section{Introduction}

An overlooked and misunderstood process in many global coarse-scale vegetation simulation models, such as Dynamic Global Vegetation Models (DGVMs), is the role that wildland fire plays in

\footnotetext{
The use of trade or firm names in this paper is for reader information and does not imply endorsement by the U.S. Department of Agriculture of any product or service. This paper was partly written and prepared by U.S. Government employees on official time, and therefore is in the public domain and not subject to copyright.

* Corresponding author. Tel.: +1 406239 6729; fax: +1 4063294877.

E-mail address: rkeane@fs.fed.us (R.E. Keane).
}

determining vegetation composition and structure (Arora and Boer, 2005; Bowman et al., 2009; Krawchuk et al., 2009; Lenihan et al., 1998; Fosberg et al., 1999). Complex ecological interactions (e.g., disturbance and mortality), non-linear feedbacks (e.g. fire, vegetation, and fuels), and spatial and temporal relationships (e.g., seed dispersal) between fire, climate, and vegetation in most ecosystems make it difficult to determine which relationships are most important for describing, understanding, and ultimately modeling ecosystem and vegetation dynamics from fine (landscape) to coarse (DGVM) scales (Lauenroth et al., 1993; Neilson et al., 2005). Ecological modeling has improved our understanding of these interactions with an ever increasing number of theoretical community, patchscale, and landscape models that have become quite successful 
at exploring climate-disturbance-vegetation interactions (Seidl et al., 2011; Baker, 1989; Loehle and LeBlanc, 1996; Lauenroth et al., 1998; Keane and Finney, 2003). However, coarser scale models of climatic effects on disturbance and vegetation change (regional to global) may be so computationally intensive and complex that many fine scale interactions are represented simplistically or eliminated altogether. Some global models, for example, assume vegetation composition and structure do not change and only simulate climate effects on biogeochemistry and ecophysiology (Running and Nemani, 1991; Neilson and Running, 1996; Waring and Running, 1998). Other models assume that vegetation will instantaneously change in response to changing climate (e.g., stateand-transition, equilibrium biogeographical models; Prentice et al., 1993; Iverson and Prasad, 2002). And, still other models assume that disturbance regimes are minor drivers of vegetation change (see Dale and Rauscher, 1994).

The inclusion of disturbance and other extreme events into coarse- and landscape-scale dynamic computer models is difficult (Lenihan et al., 1998; Fosberg et al., 1999; Perry and Millington, 2008; Pfeiffer et al., 2013; Thonicke et al., 2001) and few models have explicitly incorporated the spatial relationships between disturbance and other ecological processes at appropriate scales (Arora and Boer, 2005; Urban et al., 1991; Girod et al., 2007). Wildland fire, for example, is a ubiquitous global disturbance that is closely linked to vegetation composition and structure, climate and weather, and other disturbances processes (Swetnam, 1990; Clark, 1993; Olson, 1981; Swetnam and Baisan, 1996; Bowman et al., 2009). And conversely, fire regimes are in turn influenced by resultant vegetation dynamics, such as successional development and carbon accumulation (Agee, 1991; King et al., 2011; McKenzie, 1998; Schoennagel et al., 2004). Effects resulting from shifts in fire regimes due to climate warming (e.g., Cary and Banks, 2000; Flannigan et al., 2005) may overwhelm many other ecosystem responses to climate change, such as species growth, migration, substitution, and extinction (Weber and Flannigan, 1997), hydrology, nutrient availability, and carbon exchange (McKenzie et al., 1996; Bachelet et al., 2000). Because changes in vegetation structure and composition are dependent on the pattern, severity, and timing (e.g., season) of fire (Agee, 1993; DeBano et al., 1998; Spies et al., 2012), large non-linear changes in vegetation are likely to occur in response to climatically induced changes in fire regime (Crutzen and Goldammer, 1993; Neilson et al., 2005; Perry and Millington, 2008).

Many landscape models have been developed in the last three decades (see Baker, 1989; He, 2008; Keane et al., 2004; Li et al., 2008; Mladenoff and Baker, 1999; Scheller and Mladenoff, 2007) and we have used a special class of these models, termed Landscape Fire Succession Models (LFSMs; Keane et al., 2004), to investigate the relative importance of climate, weather variability and fuel arrangement on fire dynamics across several climates and ecosystems (Cary et al., 2006, 2009; Keane et al., 2007). We feel our efforts in these comparative simulation studies generated knowledge needed to understand landscape dynamics and provided information needed by global vegetation modelers to design efficient and parsimonious large scale vegetation models that include explicit simulations of fire. To keep simulation experiments feasible, however, our earlier studies simulated fire for only 1 year thereby keeping the vegetation and fuel composition and structure static. Because of this limited temporal depth, we could not determine the relative importance and significance of vegetation and fuel development (i.e., succession) on resultant fire regimes and landscape dynamics. This also meant that we were unable to establish the detail needed to simulate interactions of vegetation dynamics with fire on the landscape.

The problem then is to identify the role of vegetation development in the simulation of landscape dynamics in a spatial domain, especially considering the dominating influence of disturbance processes on successional dynamics. Do landscape to global vegetation models really need to describe landscape composition and pattern to ensure climate and fire regime effects are simulated properly? With this question in mind, our study objective was to explore the interaction between vegetation dynamics, weather variability, and landscape fire regimes under changing climates using ensemble simulation modeling, then specifically to describe the relative importance of vegetation development vs. fire regimes in influencing landscape dynamics under different climates and to perhaps facilitate coarse-scale model development. Understanding the role of vegetation succession on fire-prone landscapes under various climates might inform efficient and effective designs for landscape to coarse-scale models to realistically describe changes in landscape dynamics caused by warming climates.

We explored vegetation-fire-weather-climate interactions using a focused simulation experiment implemented across a suite of landscape fire succession models that were specifically designed to simulate these complex ecological process feedbacks (Cary et al., 2006). There are many advantages of implementing a simulation experiment using a number of diverse landscape models including (1) assessment of the strengths and weaknesses of each model, (2) quantification of the level of uncertainty based on consensus, (3) elimination of the dependence on results from one model, (4) improved collaboration across modelers (comparative exercises allow modelers to critically evaluate their models under novel situations usually resulting in refinements to existing models), and (5) increased learning (comparing models under a structured simulation experiments can yield new knowledge that might be helpful in understanding climate change effects and improve design of large scale models, see Cary et al., 2006).

In this study, we use the term "succession" to represent vegetation and fuel development over time. Succession is often a contentious term in vegetation ecology because it is generally used in the Clementsian context where vegetation communities develop along pathways of facilitation (Clements, 1916; Connell and Slayter, 1977). This study, however, uses the term succession to describe any form of vegetation or fuel development in any direction (progressive, retrogressive). Both vegetation development and succession are used specifically to refer to the processes that govern plant growth, reproduction, and mortality across plant species and sizes (Bazzaz, 1979). Vegetation dynamics refers to the interaction of succession with disturbance, climate, and the multitude of other ecosystem processes, and landscape dynamics refers to the interactions of vegetation, disturbance, and climate over spatial domains.

\section{Methods}

In summary, we designed a nested, factorial simulation experiment with four factors and each factor having 2-3 treatment levels to investigate fire-climate-vegetation dynamics. We implemented this experiment on 10 replicate neutral landscapes using five landscape models. Factors in the simulation experiment were selected to correspond with past modeling work (Cary et al., 2006, 2009), and also to evaluate the relative contributions of succession and fire to landscape dynamics. A nested block design was required to explore interactions across factors.

\subsection{The Models}

The five models used in this study are a small but a relatively representative fraction of the landscape fire succession models currently available (Baker, 1989; Gardner et al., 1999; He, 2008; Scheller and Mladenoff, 2007) (Table 1). We attempted to use a 


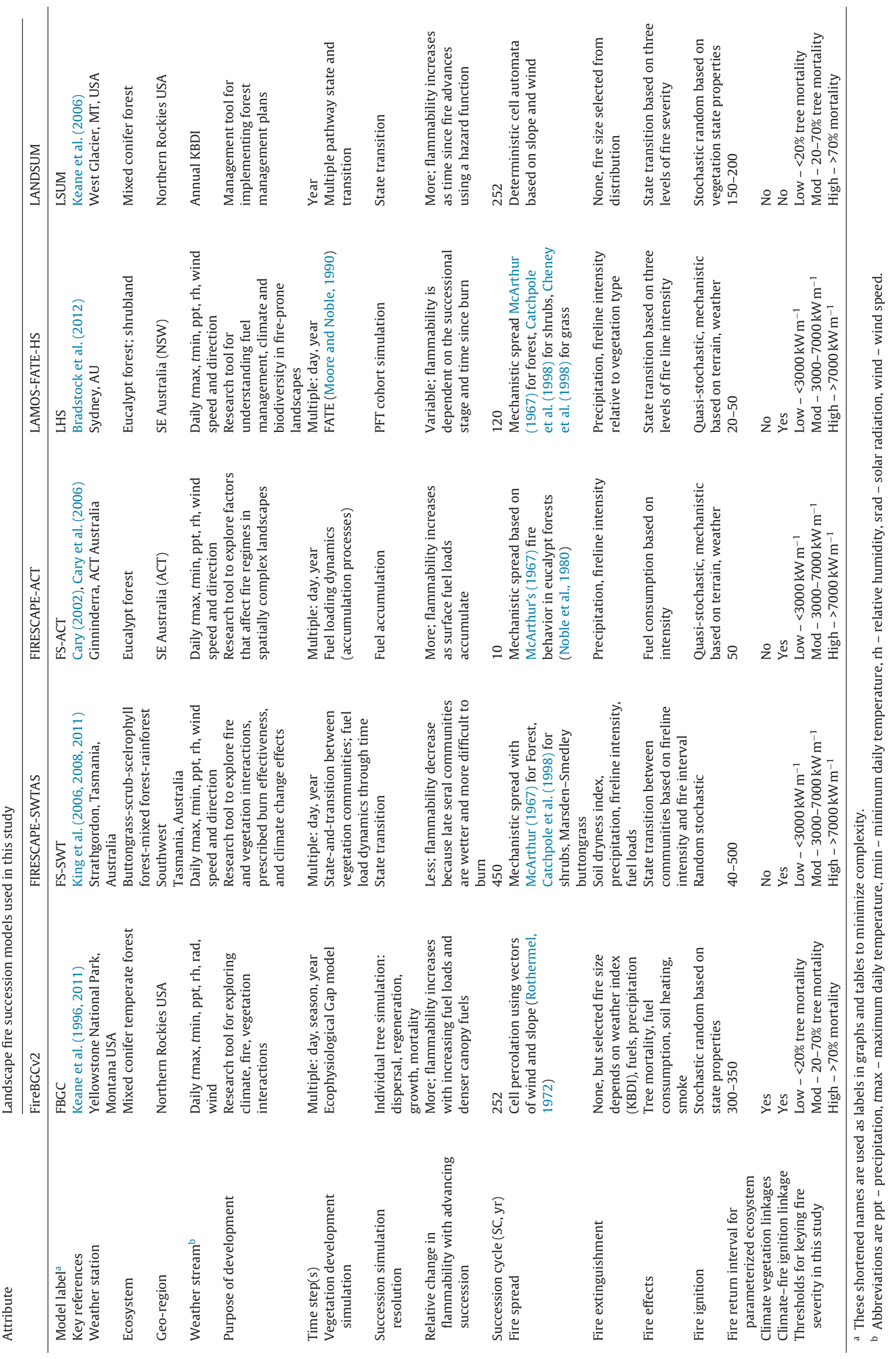


landscape model from each category of the Keane et al. (2004), He (2008), and Scheller and Mladenoff (2007) classifications, but the developers of some of the models were not available to refine their model and its input data structures to participate in this comparative experiment. We feel the five selected models represent three important classes in the Keane et al. (2004) landscape model classification (Cary et al., 2006).

FireBGCv2 is a mechanistic, individual tree succession model containing stochastic properties implemented in a spatial domain (Keane et al., 1996, 2011). It was created by fusing the FIRESUM gap model (Keane et al., 1989) with the "big leaf", ecosystem dynamics Biome-BGC model (Running and Hunt, 1993). Tree growth, organic matter decomposition, litterfall, and many other ecological processes are simulated using detailed physical biogeochemical relationships. Tree establishment and mortality are modeled using probability functions with empirically derived parameters. FireBGCv2 also includes a spatial simulation of fire on the landscape where fire is spread across the landscape based on slope and wind vectors from a fire start ignited based on fuel moisture and loading (Rothermel, 1983; Keane et al., 2002a,b). Fire effects are simulated by computing fire intensity, then estimating fuel consumption, tree mortality, and soil heating using algorithms in the embedded FOFEM model of Reinhardt et al. (1997). Daily weather inputs drive primary canopy processes (e.g., transpiration, photosynthesis and respiration) and are also used to ignite and spread fire across the landscape. Carbon allocation to the stem of a tree is used to calculate a corresponding diameter and height growth. Materials from trees (fallen needles, leaves, and branches) are added to the fuelbed and eventually decompose based on available water, nitrogen, and light. Cone crops are stochastically generated and subsequent seed dissemination is spatially modeled across the landscape using empirical dispersal relationships representing wind and bird dispersal.

FIRESCAPE-ACT simulates fire regimes for Eucalyptus dominated landscapes in southeastern Australia (Cary and Banks, 2000). It operates on a daily time step that switches to hourly whenever a fire ignites. Ignition locations are generated from an empirical model of lightning strikes (Cary, 1998). The probability of ignition is associated with macro-scale elevation reflecting the effect of mountain range storm occurrence. Daily weather is generated by a modified version of the Richardson-type stochastic climate generator (McCarthy and Cary, 2002). The spread of fire from a pixel to its immediate neighbors is a function of elliptical fire spread and Huygens' Principle (Anderson et al., 1982), although topography, fuel load and wind speed and direction result in nonelliptical fires. Rate of spread of the head fire is determined from fire behavior algorithm associated with McArthur's Forest Fire Danger Meter (McArthur, 1967). Fuel loads are modeled using Olson's (1963) model of biomass accumulation parameterized for a range of Australian systems (Fox et al., 1979; Walker, 1981; Raison et al., 1983). Fuel load is calculated before each pixel burns based on the years since last burn and how much fuel has accumulated since the last fire. Fireline intensity $\left(\mathrm{kW} \mathrm{m}^{-1}\right)$ is calculated for the spread of fire from one cell to the next to determine fire extinguishment.

FIRESCAPE-SWTAZ is a modification of the FIRESCAPEACT model to simulate fire regimes for buttongrass/sclerophyll/ rainforest landscapes in Tasmania, Australia (King et al., 2006, 2008). A state-and-transition model is used for successional trajectories between cool, moist buttongrass moorland, shrubland, sclerophyll (eucalypt), mixed forest, and rainforest communities depending on the frequency and intensity of fire events (King et al., 2008). Each pixel is updated before they burn to ensure that the vegetation and fuel loading are correct. Vegetation is evaluated immediately after it burns to determine if the same community will remain, or an alternate 'earlier succession' community will replace it as a consequence of a series of rules regarding the frequency and intensity of past fire events. Fuel dynamics are modeled in an identical manner to those in FIRESCAPE-ACT. Ignitions occur randomly across the landscape, with daily and hourly historical Australian Bureau of Meteorology weather data looped through time. Fire behavior is modeled using algorithms specific to each vegetation community: (1) buttongrass moorlands (Marsden-Smedley and Catchpole, 1995a,b, 2001; Marsden-Smedley et al., 1999, 2001); (2) shrublands (Catchpole et al., 1998); (3) forest (McArthur, 1967; Noble et al., 1980).

LAMOS-FATE-HS simulates dynamics of the dry sclerophyll forests of southeastern Australia using both the model (FATE) and plant functional type (PFT) parameterization from Moore and Noble (1990) in the LAMOS modeling shell (Lavorel et al., 2000). There are four PFTs including a tall lignotuberous eucalypt, a poa grass and two shrubs, one having seed release conditioned by fire. The FATE model is deployed over a raster grid with a separately parameterized seed dispersal algorithm for each PFT. Dispersal is mostly modeled using a continuous kernel algorithm (Lavorel et al., 2000). Community succession status is updated yearly, soil moisture, adapted from Rotstayn et al. (2006) and Roderick et al. (2007), is updated daily. Fire spread is updated hourly using the same spread algorithm as FIRESCAPE. Separate rates of spread calculations are taken from Noble et al. (1980) for forests and Cheney et al. (1998) for grass. Effects of fires on community structure are handled by the FATE model. Fuel loads are modeled using Olson (1963) with parameters from Conroy (1996) with each PFT contributing to the fuel load in proportion to its abundance. FATE has no climate linkages. Temporal frequency distribution of ignitions varies throughout the year based on lightning activity in the Sydney region (Kuleshov et al., 2002), while ignition locations have a uniform random distribution.

The LANDscape SUccession Model (LANDSUM) is a spatially explicit vegetation dynamics simulation program wherein succession is treated as a deterministic process using a stateand-transition pathway approach (frame-based), and disturbances (e.g., fire, insects, and disease) are treated as stochastic processes with all but wildland fire occurring at the polygon scale (Keane et al., 2002b, 2006). For wildland fire simulations, ignition locations are random in LANDSUM and fire spread is simulated from user-specified wind speed and direction, slope, and binary fuel type (burn, no-burn) determined from the succession stage. LANDSUM was designed as a management tool for evaluating alternative management scenarios with a minimal set of input conditions (no explicit simulation of fuels, weather or lightning), so climate was not explicitly included in the model. Climate was included for this study by computing the daily Keetch-Byram Drought Index (KBDI) and comparing the maximum value to the index ranges 200-400, 400-600, and 600+ to decide the climate index that references the scalars of $0.5,1.0$, and 2.0 , respectively, for fire frequency probabilities and fire size computations. These scalars, along with fire size and probability parameters, were estimated from fire history data compiled for a lodge-pole pine (Pinus contorta) dominated landscape in west-central Montana, USA (Schmidt et al., 2002; Holsinger et al., 2006).

\subsection{The Factors}

The effect of vegetation development on landscape dynamics was represented by the Succession factor with two treatments: (1) a Static $(S)$ landscape where fires are simulated but their effects do not affect succession and vegetation/fuels do not develop over the simulation period, and (2) Dynamic $(D)$ succession where all fire effects are simulated along with the development of vegetation and associated fuels (Table 2). The Fire factor represents the influence of wildland fire on landscape change and was designed 
Table 2

The experimental design for this comparative model simulation study. Each of the six models simulated 10 replicates for each treatment in each of the four factors ( 240 runs per model). Also shown are the analysis variables using in statistics and graphing.

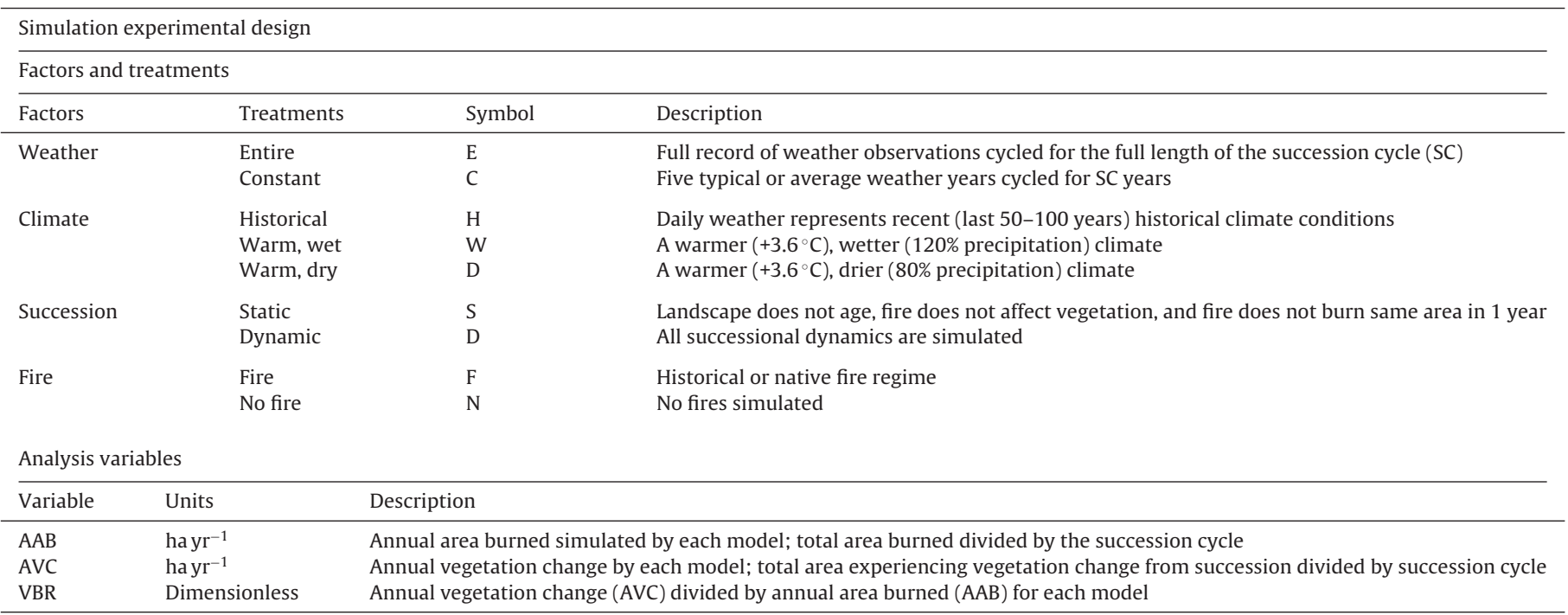

to quantify the importance of fire on landscape dynamics as it interacts with vegetation development. Here we implemented a full historical fire regime (Fire, $F$ ) as one treatment and then simulated a "no fires" or fire exclusion treatment across the landscape (No fire, $N$ ).

Factors that govern fire and vegetation dynamics were also included in the simulation design (Table 2). To study the effect of weather and its inherent variability on vegetation-fire interactions, we created the Weather factor that consists of two treatments represented by two separate streams of daily climate data. The first treatment is the actual weather data stream (Entire, E), which incorporates all variability recorded at or near the landscape for which the model was originally developed and for which the model was parameterized in this study (Table 1). The entire weather stream was looped for the full simulation time span. The second weather treatment (Constant, $C$ ) was created by selecting five of the near-median weather years in the weather record, then randomly selecting the order of these years and cycling these 5 years for the entire simulation (Cary et al., 2006). These near-medium years had low variability because they were selected as the years with the closest annual average daily temperature and annual average daily precipitation to the annual mean temperature and precipitation for all years in the historical weather record (Cary et al., 2009).

The Climate factor was employed in this study to represent projected changes in future climate and its effect on vegetation-fire dynamics. The same three climates that were used in Cary et al. (2006) were also used in this study. The first climate level is Historical $(H)$ climate, represented by the weather stream (entire or constant) recorded for each models' landscapes; there was a different weather stream for each model (Table 1). The second climate treatment is a warmer-Wetter $(W)$ climate change scenario where daily values from the historical climate were modified by adding $3.6^{\circ} \mathrm{C}$ (mid-range of projected global average temperature increase of $1.4-5.8^{\circ} \mathrm{C}$ ) to maximum and minimum temperature each day, and by increasing daily rainfall amounts $20 \%$ by multiplying them by 1.2 (IPCC, 2007). The warmer-Drier (D) climate treatment was created by adding $3.6^{\circ} \mathrm{C}$ to daily minimum and maximum temperatures similar to the warmer-wetter but the daily precipitation values were reduced by $20 \%$ by multiplying them by 0.8 (IPCC, 2007).

\subsection{Simulation design}

Each modeler was required to develop a vegetation classification for 10 successional classes based on the range of their modeled state variables. For example, 10 ordinal classes of fuel loadings were created for FIRESCAPE-ACT because that model simulates succession as fuel accumulation (Table 1). In FireBGCv2, simulated tree characteristics were classified to 10 lodgepole pine structural stages based on the dominant tree species and mean diameters. We selected 10 classes because it best represented the resolution of successional development across all models (Table 1).

Two spatial data layers were created for input to all models. They were raster layers of $1000 \times 1000$ square pixels (cells) with each pixel having a side of $50 \mathrm{~m}$ giving the simulation landscape extent of $2500 \mathrm{~km}^{2}$. The digital elevation model layer that represented topography was input as a flat landscape with an elevation of $1000 \mathrm{~m}$ MSL. We decided not to include topography as an additional factor because previous studies found that landform did not significantly influence simulated fire dynamics (Cary et al., 2006). The second layer was the initial vegetation succession stages that characterized the structure and composition of the initial landscape. We created 10 maps of 10 classes of succession (vegetation/fuels stages) using a square design with a random ordering of 10 map units with 100 ha patch sizes (Fig. 1) following a design used in past studies (Cary et al., 2006, 2009). These layers were used as replicates in our modeling effort. For initialization, each modeler modified their model to assign the appropriate values to all state variables for the 10 succession classes. LANDSUM, for example, simulated succession using a state-and-transition pathway approach so pathways were built for lodgepole pine that contained 10 linked succession classes.

The length of the simulation runs (years) was specific to each model so as to standardize all simulation results to one succession cycle across all models (Table 1). Each modeler estimated the simulation time (years) it took for their model to reach the last stage in successional development (class 10) in the absence of disturbance beginning at the first stage. This simulation time span was called the succession cycle (SC) and all model results were output for three times during each simulation: (1) year one, (2) year that is approximately half the succession cycle ( $\mathrm{SC} / 2)$, and (3) SC year. 



\section{Succession \\ Class}
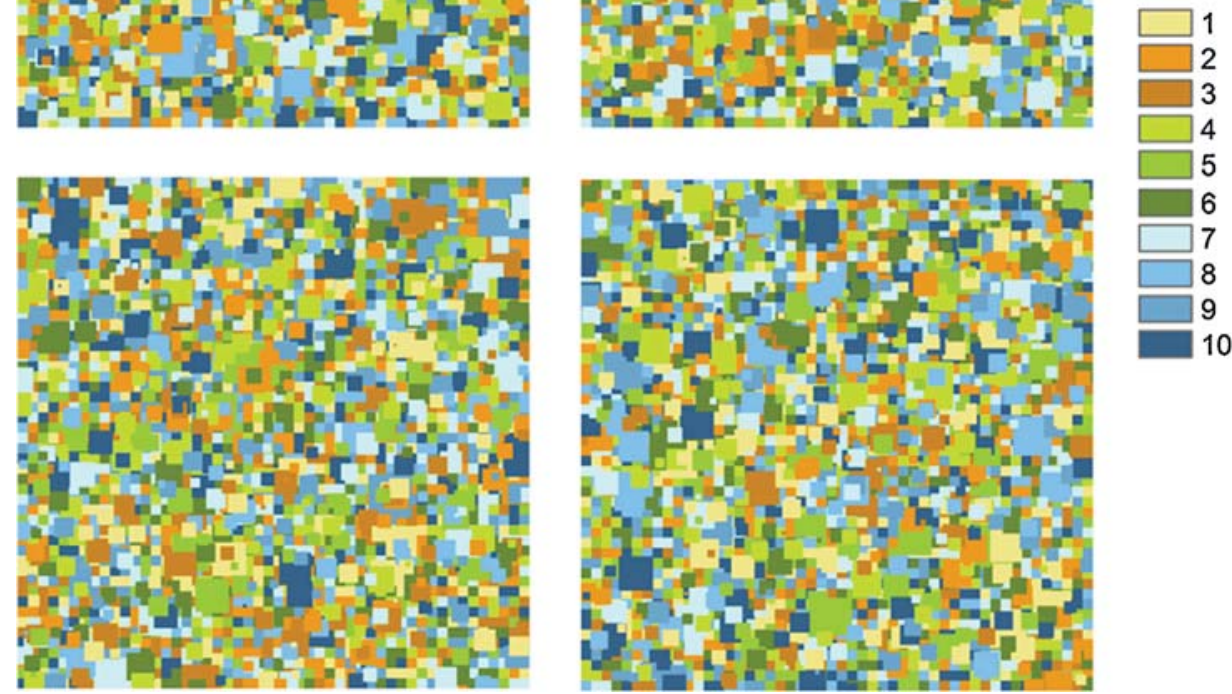

Fig. 1. Four of the 10 initial vegetation/fuel maps used to represent the initial landscape for all models. We created 10 of these maps by randomly assigning $1-10$ classes to each 100 ha patch. These vegetation/fuel maps were used as replicates in the study.

Several model output variables were used as response variables for our analysis. Area burned $\left(\mathrm{km}^{2}\right)$ and number of fires served as representations of the fire dynamics and were summed across all simulation years to each reporting time (years one, SC/2 and SC). Area burned was also output by fire severity class - low, moderate, and high - using the criteria at the bottom of Table 1 for each landscape. To describe successional dynamics, each modeler also modified their model to output the number of pixels that changed vegetation stages through the simulation (progress through one of the 10 vegetation/fuel categories), summed across the entire landscape and across all simulation years (vegetation change; $\mathrm{km}^{2}$ ). This count does not include area that changed vegetation type due to fire effects. Areas occupied by the 10 vegetation classes on the simulated landscape were also output at each reporting time (year one, $\mathrm{SC} / 2$ and SC). It may appear that the arbitrary selection of $10 \mathrm{veg}-$ etation classes may influence the rate of successional replacement (more classes mean more vegetation change), but we assumed that the number of classes was balanced by area and time in our simulations (i.e., the same number of pixels change over the succession cycle regardless of number of classes). In summary, each model was used to simulate 10 replications of all combinations of the four factors $(240$ simulations $=2$ weather $\times 3$ climate $\times 2$ succession $\times 2$ fire $\times 10$ replicates) with each replicate starting with a new vegetation map on a flat landscape. A total of 26 variables were output for each of the three time periods $(1, S C / 2, S C)$. An equilibration period (i.e., "spin-up") was not included because it added unwanted complexity to an already complex simulation design (i.e., each model required a different length equilibration period and some models were not equilibrium models), it would deemphasize initial conditions across models, and it would increase time and resources required for the 240 simulations.

\subsection{Analysis}

Preliminary statistical analyses revealed that the number of fires and area burned response variables were similar across most models so we decided to report only area burned. We then scaled all 26 response variables by simulation time to ensure consistent comparisons across all models. This involved dividing the cumulative area burned (pixels) and the amount of vegetation change (pixels) each by the number of simulation years (succession cycle) and multiplying by $0.25\left(50 \mathrm{~m} \times 50 \mathrm{~m}\right.$ pixels $\left.=2500 \mathrm{~m}^{2}\right)$ to calculate two new statistics - annual area burned (AAB, $\mathrm{km}^{2} \mathrm{yr}^{-1}$ ) and annual vegetation change ( $A V C, \mathrm{~km}^{2} \mathrm{yr}^{-1}$ ). We also created a ratio of vegetation change (AVC) to annual area burned (AAB) called vegetation burn ratio ( $V B R=A V C / A A B$, dimensionless) to understand the relationship between fire and vegetation.

We then performed a full factorial multivariate ANOVA on the simulated AAB, AVC, and VBR data across all models for all simulations and investigated the effects of all factors, treatments, and their interactions and reported only the proportion of explained variance $\left(R^{2}\right)$ to be consistent with the other comparative modeling studies (Cary et al., 2006, 2009). Unlike the Cary et al. (2006, 2009) studies, we decided not to transform any of the response variables to natural $\log$ based on the results of an extensive analysis of the ANOVA results that revealed most residuals were normally distributed for all models and scenarios.

\section{Results}

The relative proportions of each succession class for the simulation landscape predicted by each model for the middle (SC/2) and ending (SC) simulation years for each climate scenario with and 

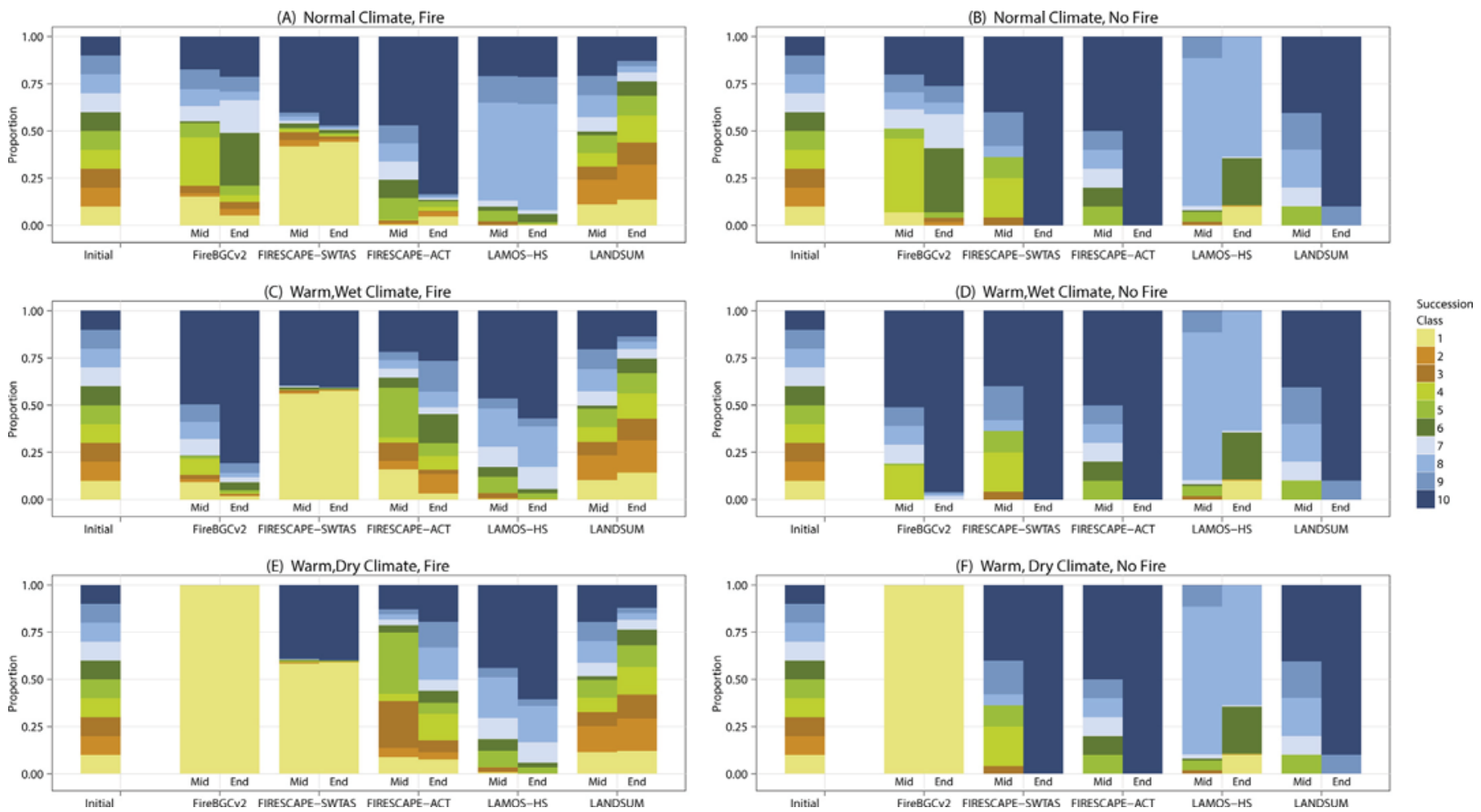

Fig. 2. Charts showing the simulated proportion of the 10 successional communities for halfway and at the end of the simulation for each model under the entire weather scenario using the A) historical climate with fire, B) historical climate without fire, C) warm, wet climate with fire, D) warm, wet climate without fire, E) warm, dry climate with fire, and E) warm-wet climate without fire. Each chart contains the even distribution of the 10 successional communities at the start of the simulation.

without fire provide critical information for interpreting results of the simulation experiment (Fig. 2). Fire tends to maintain a wide diversity of succession classes on the landscape for all but the FIRESCAPE-SWTAS model where simulated vegetation classes tended to be dominated by late seral and early communities (Fig. 2a). In FIRESCAPE-SWTAS, frequent fire tends to create stable buttongrass moorland communities (Fig. 2a), and as fire increases in warmer, drier climates, there is a general increase in buttongrass communities with a corresponding decrease in all but the oldest, least flammable seral rainforest types. In warmer climates, fires tend to create more diverse community patterns in all but the FireBGCv2 climates where the increase in fire coupled with the warmer climate has transitioned the landscape to shrub-herb communities (Fig. 2c and e). In general, successional vegetation/fuel type distributions at the end of the simulations with fire differs for each model reflecting the fundamental differences across models and the base ecosystems used to parameterize each models simulation.

Theoretically, in the absence of fire, the simulation landscape should be composed of only the latest seral community type (class 10 ) by the ending year for all models (Fig. 2b). However, some models (LANDSUM, FireBGCV2, LAMOS) still have mid-seral communities probably because of inadequate parameterizations of the succession cycle (SC) and fire frequency (Table 1), and the difficulty of describing the large state space of the model in 10 classes. Rates of succession without fire are surprisingly comparable across all models as evidenced by mid- to end-SC successional class distributions (Fig. 2b), and the fact that the rates of successional advancement seem to somewhat stable across the three climate scenarios (Fig. 2d and f), except for FireBGCv2 which predicts the entire landscape is not suitable for lodgepole pine under warmer climates and all other parameterized conifers that might replace lodgepole pine have yet to disperse propagules onto the landscape after 252 years.

The simulated annual area burned (AAB) statistics were somewhat inconsistent $\left(0.4-297 \mathrm{~km}^{2} \mathrm{yr}^{-1}\right)$ across all models with the range lying between the two FIRESCAPE models: SWTAS burned few lands $\left(<51 \mathrm{~km}^{2} \mathrm{yr}^{-1}\right)$ while ACT had the most fire (9-325 $\mathrm{km}^{2} \mathrm{yr}^{-1}$ ) (Table 3; Fig. 3). Most landscape models simulated a major increase in area burned as the climate became warmer and drier (factor of 2-10 times), except for LANDSUM, which simulated only a $10 \%$ increase. Interestingly, both the variability and the magnitude of $A A B$ generally increased with increasing temperatures for all models (Fig. 3). The variability in AAB was the lowest for Tasmania FIRESCAPE-SWTAS simulations $(<0.005)$ and highest for southeastern Australia FIRESCAPE-ACT simulations (1.6-35.7). There was significantly less area burned $(p<0.05)$ when succession was held constant for all models with percent decreases ranging from 50 to $90 \%$. And there was more area burned when the entire (high variability) weather stream was used, especially when succession was dynamic, for all but FIRESCAPE-ACT and LANDSUM; constant weather resulted in a decrease in AAB for FIRESCAPESWTAS simulations with dynamic succession.

The annual change in vegetation from succession only (AVC) also varied across most models ranging from 0.1 to $2081 \mathrm{~km}^{2} \mathrm{yr}^{-1}$; again the span simulated by the two FIRESCAPE models; SWTAS vegetation change ranged from 0.1 to 3.3 and ACT results ranged from 1125 to $2081 \mathrm{~km}^{2} \mathrm{yr}^{-1}$ (Table 3; Fig. 4). These simulated successional rates were significantly less (10-60\% increase) when the climate was warmer and drier over the historical climates for all models but FireBGCv2, which simulated an increase because it is one of the only models to have a close link between climate and vegetation growth. We found there were few differences in simulation results across models between constant and entire weather scenarios, except again for FireBGCv2 which simulated twice the succession rates under more variable climate (Fig. 4), but these rates were comparable across both weather scenarios under the warmer, drier climates when the landscape was converted to shrub-herb. There were relatively little differences in AVC in fire and no fire scenarios, except for both LAMOS-HS and FIRESCAPE-ACT that 
Table 3

Simulation results of the three annualized response variables for all scenarios (factors and treatments) for each landscape model (see Table 1 for definitions of each model label) across replicates with standard deviations shown in parenthesis. Note that only the Fire treatment is shown for AAB because all No Fire simulations were zero; only the Dynamic Succession treatment was shown for AVC because all Static Succession simulations were zero; and only the Fire and Dynamic Succession treatments are shown for VBR because all others were zero or infinite.

\begin{tabular}{|c|c|c|c|c|c|}
\hline \multirow[t]{2}{*}{ Factor and treatment } & \multicolumn{5}{|c|}{ Landscape succession fire model labels (see Table 1 ) } \\
\hline & FBGC & FS-ACT & FS-SWT & LHS & LSUM \\
\hline \multicolumn{6}{|c|}{ Annual area burned $\left(\mathrm{AAB}, \mathrm{km}^{2} \mathrm{yr}^{-1}\right)$} \\
\hline \multicolumn{6}{|c|}{ Dynamic succession, constant weather } \\
\hline Historical climate & $11.9(1.0)$ & $54.2(15.2)$ & $0.4(0.0)$ & $66.8(1.8)$ & $27.6(0.5)$ \\
\hline Warmer, wetter & $20.7(1.3)$ & 279.3(17.9) & $11.4(0.3)$ & $194.5(2.3)$ & $27.7(0.4)$ \\
\hline Warmer, drier & $40.7(1.6)$ & $297.0(13.4)$ & $23.5(0.2)$ & $196.3(3.4)$ & $28.9(0.7)$ \\
\hline \multicolumn{6}{|c|}{ Dynamic succession, entire weather } \\
\hline Historical climate & 11.6(1.7) & $44.9(5.9)$ & $26.4(0.4)$ & $84.5(1.8)$ & $27.9(0.6)$ \\
\hline Warmer, wetter & $25.8(1.6)$ & 217.0(11.1) & $43.7(0.4)$ & $227.2(2.7)$ & 27.1(0.7) \\
\hline Warmer, drier & $36.2(1.3)$ & 278.3(15.9) & $51.4(0.3)$ & $231.5(3.0)$ & $28.4(0.8)$ \\
\hline \multicolumn{6}{|c|}{ Static succession, constant weather } \\
\hline Historical climate & $10.7(1.1)$ & $11.6(2.3)$ & $1.0(0.0)$ & $6.6(0.6)$ & $7.6(0.2)$ \\
\hline Warmer, wetter & 23.8(1.9) & $184.2(40.1)$ & $1.5(0.0)$ & $64.0(3.8)$ & $7.6(0.2)$ \\
\hline Warmer, drier & $46.1(2.6)$ & $325.4(35.7)$ & $1.9(0.0)$ & $65.3(4.0)$ & $7.3(0.1)$ \\
\hline \multicolumn{6}{|c|}{ Static succession, entire weather } \\
\hline Historical climate & $11.0(1.0)$ & $9.0(1.6)$ & $2.4(0.1)$ & $8.4(0.5)$ & $7.4(0.1)$ \\
\hline Warmer, wetter & 23.7(1.9) & $89.2(18.2)$ & $2.8(0.0)$ & $94.5(4.7)$ & $7.4(0.1)$ \\
\hline Warmer, drier & $34.1(2.8)$ & $231.5(25.1)$ & $3.6(0.0)$ & $103.9(3.9)$ & $7.2(0.1)$ \\
\hline \multicolumn{6}{|c|}{ Annual vegetation change (AVC, $\mathrm{km}^{2} \mathrm{yr}^{-1}$ ) } \\
\hline \multicolumn{6}{|l|}{ Fire, constant weather } \\
\hline Historical climate & $44.5(0.3)$ & $1278.9(31.3)$ & $3.1(0.0)$ & $89.9(1.6)$ & $65.6(0.2)$ \\
\hline Warmer, wetter & $44.8(0.3)$ & $2008.9(42.6)$ & $1.6(0.0)$ & $129.4(1.5)$ & $65.8(0.4)$ \\
\hline Warmer, drier & $15.4(1.0)$ & $2058.8(43.4)$ & $0.6(0.0)$ & $124.5(1.5)$ & $66.4(0.5)$ \\
\hline \multicolumn{6}{|l|}{ Fire, entire weather } \\
\hline Historical climate & $94.2(1.1)$ & $1264.1(20.0)$ & $0.6(0.0)$ & $100.0(1.3)$ & $65.1(0.3)$ \\
\hline Warmer, wetter & $63.1(1.6)$ & $1899.0(24.2)$ & $0.1(0.0)$ & $131.5(2.2)$ & $65.2(0.5)$ \\
\hline Warmer, drier & $15.8(1.1)$ & 2081.1(41.4) & $0.1(0.0)$ & $128.8(1.5)$ & $66.1(0.5)$ \\
\hline \multicolumn{6}{|c|}{ No fire, constant weather } \\
\hline Historical climate & $44.6(0.3)$ & $1125.0(0.0)$ & $3.3(0.0)$ & $62.4(0.1)$ & $43.5(0.3)$ \\
\hline Warmer, wetter & $44.5(0.3)$ & $1125.0(0.0)$ & $3.3(0.0)$ & $62.4(0.1)$ & $43.5(0.3)$ \\
\hline Warmer, drier & $15.7(1.0)$ & $1125.0(0.0)$ & $3.3(0.0)$ & $62.4(0.1)$ & $43.5(0.3)$ \\
\hline \multicolumn{6}{|l|}{ No fire, entire weather } \\
\hline Historical climate & $99.6(1.1)$ & $1125.0(0.0)$ & $3.3(0.0)$ & $62.4(0.1)$ & $43.5(0.3)$ \\
\hline Warmer, wetter & $63.5(2.0)$ & $1125.0(0.0)$ & $3.3(0.0)$ & $62.4(0.1)$ & $43.5(0.3)$ \\
\hline Warmer, drier & $16.3(0.9)$ & $1125.0(0.0)$ & $3.3(0.0)$ & $62.4(0.1)$ & $43.5(0.3)$ \\
\hline \multicolumn{6}{|c|}{ Vegetation change area burned ratio (VBR, unitless) } \\
\hline \multicolumn{6}{|c|}{ Fire, dynamic succession, constant weather } \\
\hline Historical climate & $4.0(0.4)$ & $36.8(7.3)$ & $9.3(0.9)$ & $1.3(0.0)$ & $2.4(0.0)$ \\
\hline Warmer, wetter & $2.3(0.2)$ & $7.4(0.5)$ & $0.1(0.0)$ & $0.7(0.0)$ & $2.4(0.0)$ \\
\hline Warmer, drier & $0.4(0.0)$ & $7.1(0.3)$ & $<0.1(0.0)$ & $0.6(0.0)$ & $2.3(0.0)$ \\
\hline \multicolumn{6}{|c|}{ Fire, dynamic succession, entire weather } \\
\hline Historical climate & $9.5(1.1)$ & $34.0(5.4)$ & $<0.1(0.0)$ & $1.2(0.0)$ & $2.3(0.0)$ \\
\hline Warmer, wetter & $2.5(0.2)$ & $8.9(0.3)$ & $<0.1(0.0)$ & $0.6(0.0)$ & $2.4(0.1)$ \\
\hline Warmer, drier & $0.4(0.0)$ & $7.7(0.4)$ & $<0.1(0.0)$ & $0.6(0.0)$ & $2.3(0.1)$ \\
\hline
\end{tabular}

simulated the same succession rates across all climate and weather scenarios when fire was excluded. And, even though numbers for AVC were greater than $A A B$, the variabilities across simulations were much less (Fig. 3, Table 3 numbers in parentheses).

The ratio of vegetation change to area burned (VBR) provided an important index to interpret landscape dynamics with values below 1.0 indicating more change from fire than succession while numbers above 1.0 meant that succession is the more dominant process (Table 3; Fig. 5). VBR values could only be calculated for scenarios with fire and succession. In our comparative modeling experiment, the VBR was significantly different across all models. For VBR values greater than one, FIRESCAPE-ACT had the highest values (7.1-36.8) while LANDSUM ( 2.3 for nearly all scenarios), LAMOS-HS (0.6-1.3), and FireBGCv2 (0.4-9.5) simulated smaller values, and FIRESCAPE-ACT had most values greater than one (7.1-36.8). Values for VBR were somewhat different between the entire and constant scenarios with increases for FireBGCv2 (50\%), decreases for FIRESCAPE-ACT (5\%), and all other models about the same. However, values were quite different across climate scenarios with most models experiencing declines (1-100\%) and most values were below 1.0 with warmer climates; fire is a more dominant process under warmer future climates.

The proportion of $A A B$ that consisted of high severity fires also varied greatly across models and scenarios (Fig. 6a). FIRESCAPEACT, LAMOS-HS, and FireBGCV2 had less than $20 \%$ of AAB in high severity fires regardless of succession (only the entire weather scenario was used in Fig. 6), while LANDSUM predicted around $42 \%$ high severity fire and FIRESCAPE-SWTAS predicted around 20\% across all succession and climate scenarios (Fig. 6a). High severity fires tended to decrease with warmer climates for FIRESCAPE-SWTAS and LAMOS-HS, stay the same for FIRESCAPEACT and LANDSUM, and increase in FireBGCv2 (80\% high severity in warmer drier climates). When succession was held static (Fig. 6b), FIRESCAPE-ACT and LAMOS-HS had less area burned but the same 

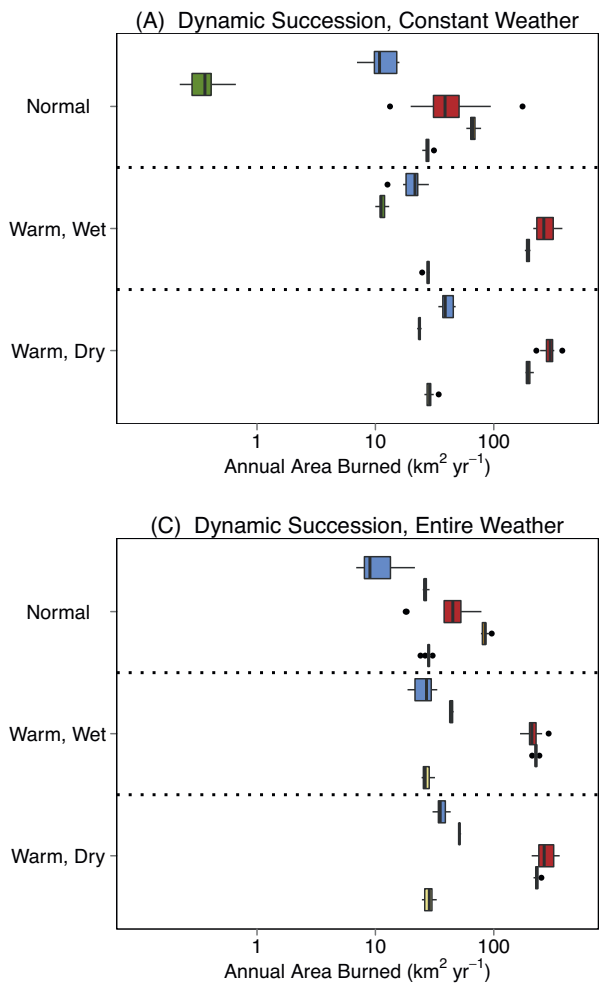

(B) Static Succession, Constant Weather

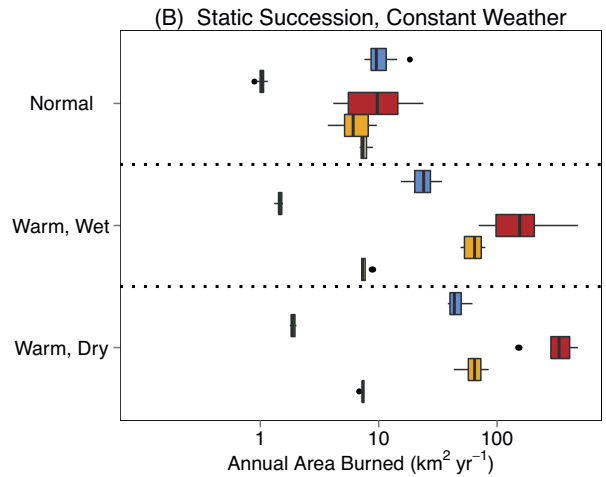

(D) Static Succession, Entire Weather



Model Order

PIRESCAPE-SWTAS

PIRESCAPE-ACT

星LAMOS-HS

GANDSUM

Fig. 3. Box and whisker plots of annual area burned ( $A A B, \mathrm{~km}^{2} \mathrm{yr}^{-1}$ ) by succession (dynamics and static) and weather scenarios (constant and entire) for each model under the three climate scenarios (historical, warm-wet, warm-dry) for only simulations with fire: A) succession and constant weather, B) no successional development under constant weather, C) succession under weather from the entire record, and D) no successional development under entire weather.

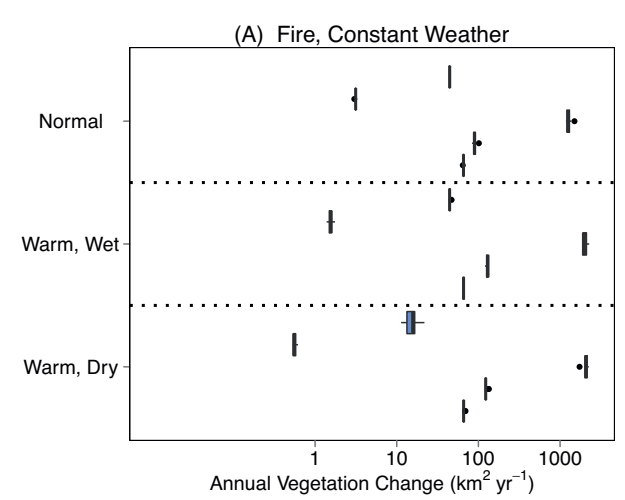

(C) Fire, Entire Weather

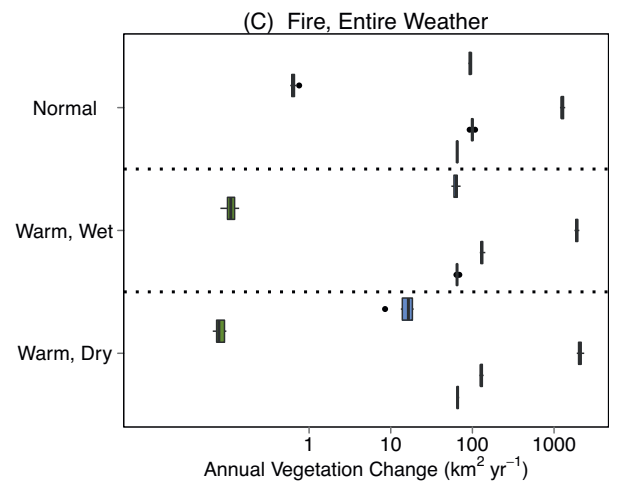

(B) No Fire, Constant Weather

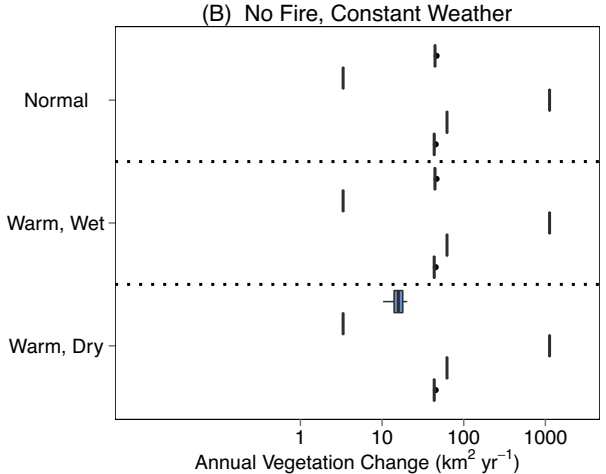

(D) No Fire, Entire Weather

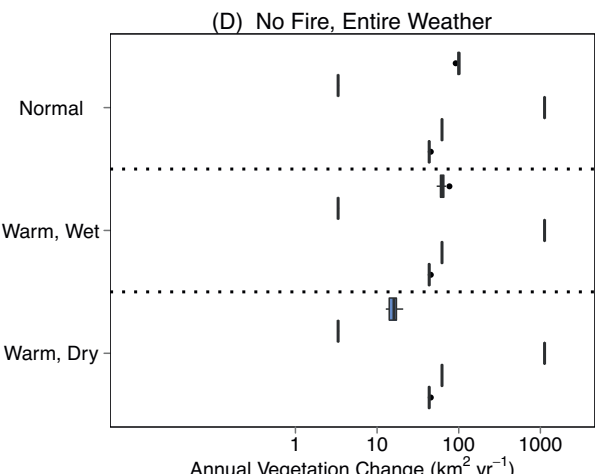

Model Order

FireBGCV2 2 FIRESCAPE-SWTAS

FIRESCAPE-ACT

GAMOS-HS

㇒LANDSUM

Fig. 4. Box and whisker plots of annual vegetation change ( $\mathrm{AVC}, \mathrm{km}^{2} \mathrm{yr}^{-1}$ ) by fire (no fire and fire) and weather scenarios (constant and entire) for each model under the three climate scenarios (historical, warm-wet, warm-dry) for only simulations with dynamic succession: A) fire and constant weather, B) no fire under constant weather, C) fire under weather from the entire record, and D) no fire development under entire weather. 


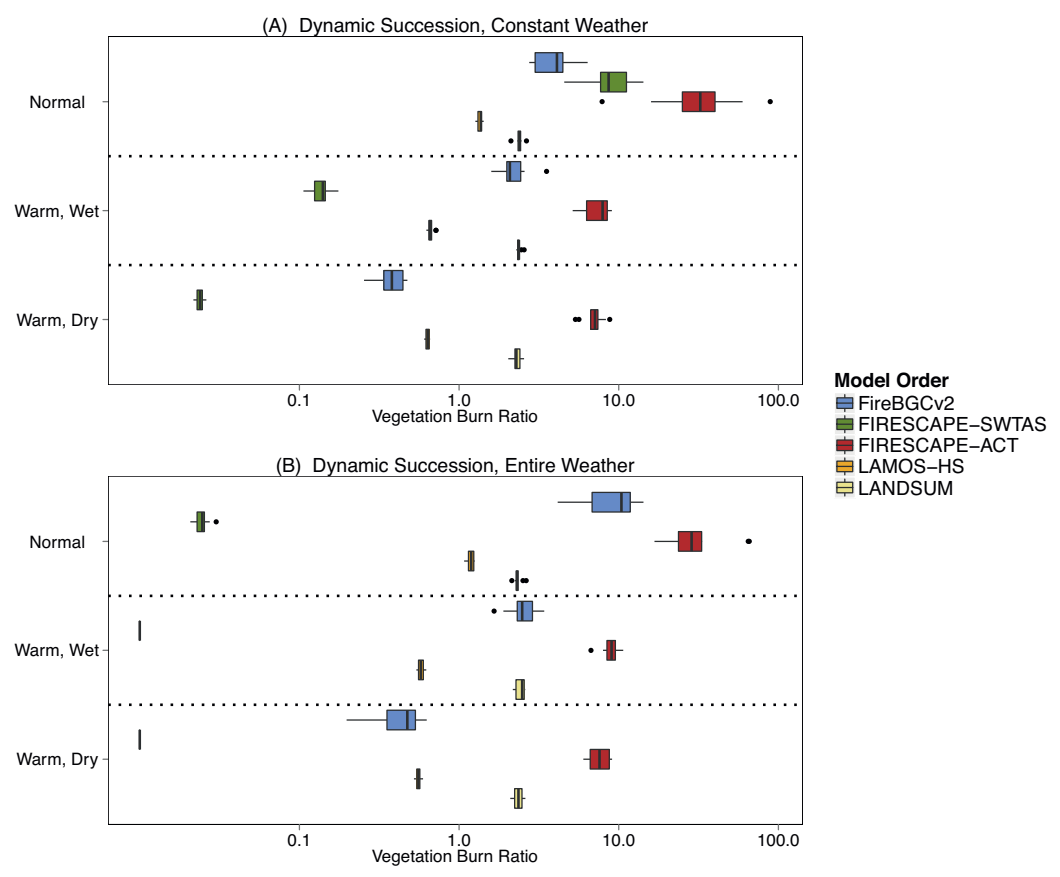

Fig. 5. Box and whisker plots of vegetation burn ratio (VBR) by model and climate scenarios for A) constant and B) entire weather scenarios for simulations with dynamic succession and fire.

proportion of high severity fires, LANDSUM stayed about the same, FIRESCAPE-SWTAS had less fire and less high severity fires, and FireBGCv2 had more high severity fires (Fig. 6b). For AVC, the proportion of high severity fire decreased from around $42 \%$ for
LANDSUM to $22 \%$ for FIRESCAPE-SWTAS, $15 \%$ for LAMOS-HS, and $<1 \%$ for FIRESCAPE-ACT, with little difference between climate scenarios (Fig. 6c). The same relationships held for vegetation burn ratio (VBR, Fig. 6d).
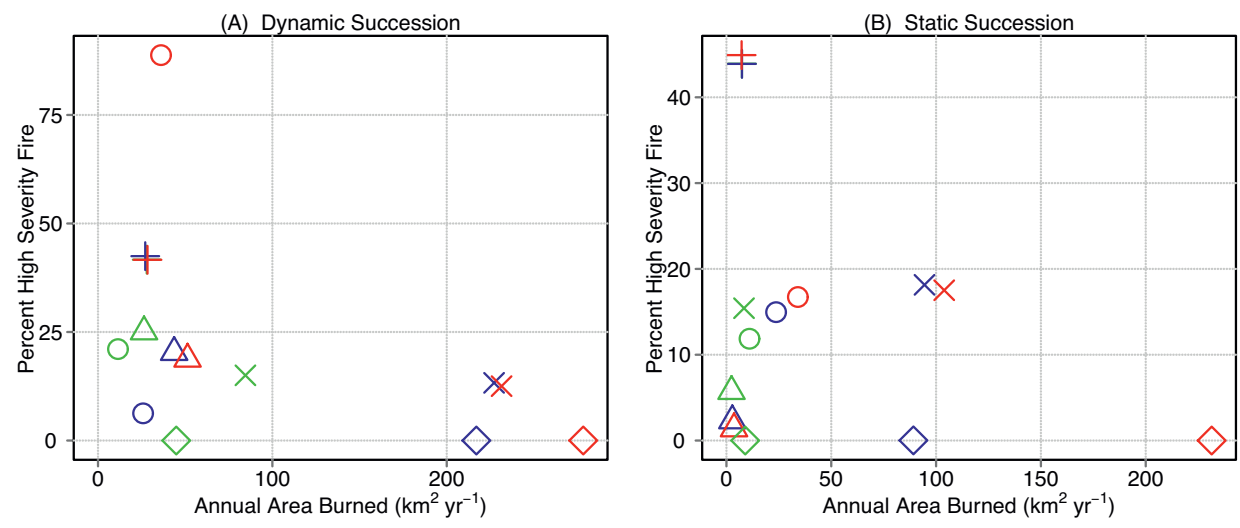

Climate

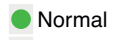

Warm, Wet

Warm, Dry

Model

O FireBGCv2


$\triangle$ FIRESCAPE-SWTAS

$\triangle$ FIRESCAPE-ACT

$X$ LAMOS-HS

+LANDSUM

Fig. 6. The mean value across all replicates of the percent of high severity fires simulated by all models for each climate scenario for the entire weather scenario for A) annual area burned $\left(\mathrm{AAB}, \mathrm{km}^{2} \mathrm{yr}^{-1}\right)$ under dynamic succession, B) annual area burned (AAB, $\mathrm{km}^{2} \mathrm{yr}^{-1}$ ) under static succession, C) annual vegetation change $\left(\mathrm{AVC}, \mathrm{km}^{2} \mathrm{yr}^{-1}\right)$, and $\mathrm{D}$ ) vegetation burn ratio (VBR). 
Table 4

Relative sums of squares attributed to different sources of variation (explained $R^{2}$ ) from the ANOVA analysis for the four factors (weather, climate, fire, succession) for each landscape model (FS-ACT, FBGC, LSUM, FS-SWT, and LHS, see Table 1 for definitions of each model label) across replicates.

\begin{tabular}{|c|c|c|c|c|c|}
\hline \multirow[t]{3}{*}{ Factor and interaction } & \multicolumn{5}{|c|}{ Landscape succession fire model labels (see Table 1) } \\
\hline & FBGC & FS-ACT & FS-SWT & LHS & LSUM \\
\hline & \multicolumn{5}{|c|}{ Annual area burned (AAB) } \\
\hline Succession & 0.00 & 0.04 & 0.09 & 0.28 & 0.98 \\
\hline Climate & 0.79 & 0.65 & 0.28 & 0.41 & 0.00 \\
\hline Weather & 0.00 & 0.03 & 0.42 & 0.00 & 0.00 \\
\hline Succession $\times$ Climate & 0.01 & 0.03 & 0.01 & 0.03 & 0.00 \\
\hline Succession $\times$ Weather & 0.01 & 0.00 & 0.01 & 0.00 & 0.00 \\
\hline Climate $\times$ Weather & 0.03 & 0.01 & 0.16 & 0.01 & 0.00 \\
\hline Succession $\times$ Climate $\times$ Weather & 0.00 & 0.00 & 0.01 & 0.01 & 0.00 \\
\hline \multirow[t]{2}{*}{ Model } & 0.84 & 0.76 & 0.98 & 0.74 & 0.98 \\
\hline & \multicolumn{5}{|c|}{ Annual vegetation change (AVC) } \\
\hline Fire & 0.01 & 0.60 & 0.15 & 0.62 & 0.99 \\
\hline Climate & 0.66 & 0.18 & 0.14 & 0.16 & 0.00 \\
\hline Weather & 0.18 & 0.00 & 0.15 & 0.00 & 0.00 \\
\hline Fire $\times$ Climate & 0.00 & 0.18 & 0.14 & 0.16 & 0.00 \\
\hline Fire $\times$ Weather & 0.00 & 0.00 & 0.15 & 0.00 & 0.00 \\
\hline Climate $\times$ Weather & 0.14 & 0.00 & 0.14 & 0.00 & 0.00 \\
\hline Fire $\times$ Climate $\times$ Weather & 0.00 & 0.00 & 0.14 & 0.00 & 0.00 \\
\hline \multirow[t]{2}{*}{ Model } & 0.99 & 0.99 & 0.99 & 0.94 & 0.99 \\
\hline & \multicolumn{5}{|c|}{ Vegetation: burned area burned ratio (VBR) } \\
\hline Climate & 0.60 & 0.57 & 0.43 & 0.18 & 0.05 \\
\hline Weather & 0.08 & 0.00 & 0.40 & 0.05 & 0.00 \\
\hline Climate $\times$ Weather & 0.14 & 0.00 & 0.15 & 0.11 & 0.02 \\
\hline Model & 0.82 & 0.57 & 0.98 & 0.34 & 0.07 \\
\hline
\end{tabular}

Results from the ANOVA analysis of the simulation experiment show that all four factors (climate, weather, succession, and fire) may drive landscape dynamics with explained variances $\left(R^{2}\right)$ ranging from 0.57 to 0.99 (Table 4 ). It appears that climate is the overriding driver in fire dynamics $(A A B)$ explaining the majority of the variation for all but the LANDSUM model. Weather $\left(R^{2}=0.42\right)$ was more important than climate $\left(R^{2}=0.28\right)$ only for the FIRESCAPE-SWTAS model, and LAMOS-HS has succession $\left(R^{2}=0.28\right)$ as an important factor. LANDSUM burned area is only related to succession because the climate is simplistically linked only to fire and it is simplistic. As expected, climate drives both fire (AAB, $\left.R^{2}=0.79\right)$ and succession (AVC, $\left.R^{2}=0.66\right)$ for FireBGCv2 because all fire and vegetation dynamics are emergent properties from climate. In all other models, fire is more important than climate for AVC (Table 4). LAMOS-HS, FireBGCv2, and FIRESCAPE-ACT had significant interactions between fire-climate and climate-weather $\left(R^{2} \sim 0.15\right)$. And last, climate is more important than weather for VBR across all models but many show major interactions between the two.

\section{Discussion}

It is evident from this comparative model simulation experiment that wildland fire (AAB) and succession (AVC) are major agents of landscape dynamics causing approximately 1-12\% change per year. Their relative importance in landscape dynamics ultimately depends on the ecosystem simulated, the climate input to the model, and the model used to simulate that ecosystem (Figs. 3 and 4). In general, we found succession caused more landscape change than wildland fire with VBR values nearly always greater than one, but, as climates warm, VBR values drop below zero as more fire is simulated (Table 3). However, it is important to note that succession-mediated landscape change (AVC; Table 3 ) is more subtle than change from fire (AAB; Table 3 ); succession change is from one type to the next, whereas fire can cause major vegetational shifts from late to early seral communities. While most models simulated more land area altered by succession than fire by factors ranging from 1.2 to 34 (VBR) for historical climates with entire weather, fire changed more area than succession in the Tasmania simulations (FIRESCAPE-SWTAS) (Table 3). VBR values decreased overall with increasing fires under warmer, drier climates in the future (Fig. 5) with both FIRESCAPE-SWTAS and LAMOS-HS simulating more landscape change from fire than succession. Landscapes with high VBR values have less fire, slow succession, or both, while landscapes with low VBR values have more fires, rapid succession, or both. Contrary to other studies, we also found that the variability in weather was not a significant factor in predicting future landscape dynamics under current and future climates.

\subsection{Model comparison issues}

Reasons for these large disparities in factors and treatments across models stem from both differences in models and differences in the ecosystems that each model simulated (Table 1). The Tasmania landscape simulated by FIRESCAPE-SWTAS was composed of stable community types with long transition times (high SC; Table 1), such as buttongrass moorlands, that rarely changed, as there was usually sufficient amounts of burning in these early seral communities. The paradox is that these stable types were created over millennia by frequent aboriginal burning (Jackson, 1968). The FIRESCAPE-SWTAS model simulated these stable communities using a state-and-transition approach that resulted in only $26 \mathrm{~km}^{2} \mathrm{yr}^{-1}$ changed because of fire, but only $0.6 \mathrm{~km}^{2} \mathrm{yr}^{-1}$ changed from succession (Table 3 ). In contrast, the FIRESCAPE-ACT model simulated nearly 25 times more area changed by succession $\left(1264 \mathrm{~km}^{2} \mathrm{yr}^{-1}\right)$ over fire $\left(45 \mathrm{~km}^{2} \mathrm{yr}^{-1}\right.$; Table 3$)$, primarily because succession is modeled in FIRESCAPE-ACT as fuel accumulation, and the fuel accumulation curve is asymptotic with the maximum reached in around 10 years. This means that with 10 succession classes, there is a change roughly every year, so even though fire has a high frequency ( 50 years fire return interval), rapid succession overwhelms the fire signal. In reality, the forested landscapes 


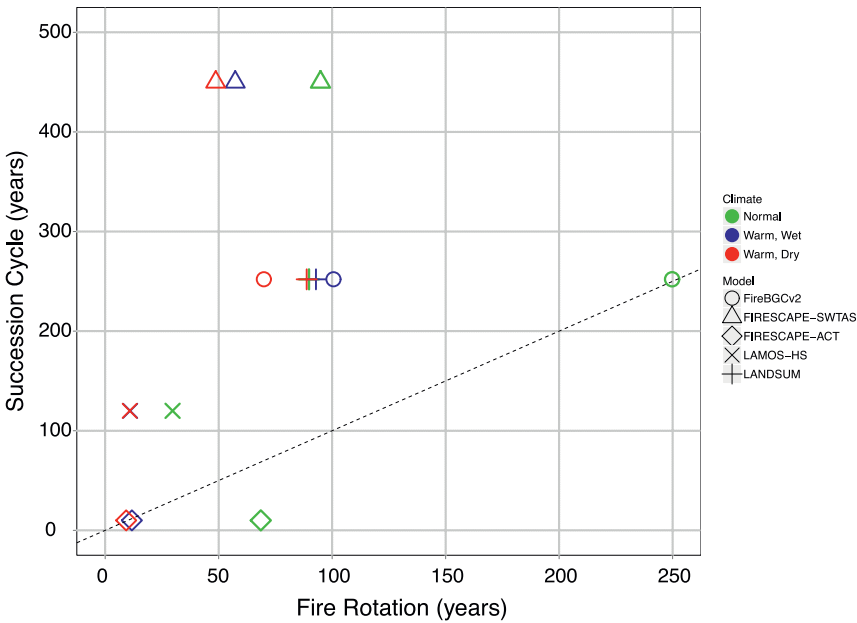

Fig. 7. The relationship of the landscape fire rotation simulated by each model for the three climate scenarios to the input succession cycle (SC). Note that the SC stays constant across all climate scenarios.

of the Australian Capital Territory are relatively stable (Vivian et al., 2008), thus the high VBR values obtained are more a reflection of succession being represented by quickly changing fuel loads in this incarnation of the model (Fig. 5).

The only model to simulate fire rotations that were greater than the input succession cycle is FIRESCAPE-ACT (Fig. 7) and this is probably because fuel loading was used to classify succession stage. All other models had higher SCs than fire rotations and their ratios (SC/fire rotation) ranged from 1.7 (LAMOS-HS) to 45.2 (FIRESCAPE-SWTAS) with differences mostly related to the individual ecosystems simulated. Fire rotations decreased (fires became more frequent) as climate became warmer and drier for all models (Fig. 7), but SC stayed constant because it was an input, so it would have been interesting to see how long it took landscapes to become comprised of only the latest succession community under the warmer climates, especially for those models that explicitly simulate climate-vegetation interactions.

Model design also contributed to differences in simulation results. Parsimonious models, such as LANDSUM, predict succession twice as important as fire (Tables 1 and 3 ), but this relationship stays the same across future climates and different weather variability because of overly generalized climate linkages to fire. Climate is linked to vegetation development for only the FireBGCv2 model (Fig. 2), where daily weather drives tree reproduction, growth, and mortality processes (Table 1; Keane et al., 2011), and as a result, there is a dynamic interaction between climate, fire, and vegetation, as evidenced by the increased fire severity under future fires (Fig. 6). Fire regimes are emergent properties for all but the LANDSUM model where fire return intervals are specified by biophysical setting (Table 1 ). And conversely, vegetation development is specified for the state-and-transition models of FIRESCAPESWTAS, FIRESCAPE-ACT, and LANDSUM, but an emergent property of LAMOS-HS and FireBGCv2. Fire growth is simulated using diverse approaches of cell percolation (FireBGCv2, LAMOS-HS), cell automata (LANDSUM), and time-dependent spread across neighboring pixels (FIRESCAPE models) (Table 1 ), but we feel that the method of fire extinguishment or termination is more important than fire spread because it dictates the amount of area burned. LANDSUM grows the fire to a stochastically selected size based on an input fire size probability distribution; FireBGCv2 has a similar method but adjusts the selected size to fire weather; and the FIRESCAPE models and LAMOS-HS simulate fire growth until the fire hits a fuelbreak (e.g., edge of simulation landscape, previously burned area) or fuels are sufficiently moist.

\subsection{Fire-vegetation-climate-weather interactions}

All models predict more area burned under future climates (Table 3 ) and this increase interacts with vegetation development to create significantly different landscapes (Fig. 2a, c, e), especially when compared to landscapes where fire has been excluded (Fig. 2b, d, f). Warmer drier climates have 2-4 times more fire than historical climates (Table 3 ), but fires in warmer climates are nearly the same severity as historical fires (Fig. 6), except for FireBGCv2, probably because as fire becomes more frequent it tends to limit fuel accumulation by burning fuels and altering vegetation development. Simulated climate interactions with fire and succession tend to create landscapes with more early successional communities (Fig. 2).

We found that differences between the two weather scenarios (constant vs. entire) were not significant for most models (Figs. 3-5). We hypothesized that weather records with small variations (constant) would have less effect on fire and vegetation change than weather streams containing full representations of historical variations, but this was not always the case. This is probably a result of the (1) coarse representation of weather in some simulation models, (2) limited number of weather years in the weather streams (i.e., small deviations across entire weather record), (3) constant rainfall across all scenarios, and (4) few drought years. Both FireBGCv2 and LANDSUM used the KBDI to simulate weather and climate effects on fire ignition and spread, which incorporates temperature (heat sum) and precipitation in an empirical index that is sensitive to periods of drought. The two FIRESCAPE models and LAMOS-HS have a more comprehensive simulation of climate and fire dynamics. It could also be that the deviations from normal in both weather streams resulted in the same fire dynamics even though the magnitudes of these deviations were much greater for the entire weather stream (Fig. 4), but the frequency and variations stayed the same across climate scenarios because daily precipitation were multiplied by factors.

\subsection{Study limitations}

Comparative modeling experiments are useful for describing uncertainty and for understanding ecological interactions across processes and scales (Cary et al., 2006, 2009). This study serves to illustrate the strengths and weaknesses of each model as it is applied to different ecosystems, landscapes, and initial conditions. However, there are limitations in our experiment that may have influenced our results. Each model is a reflection of the model developer, and each developer has their own idea of how disturbance and vegetation processes should be represented in their models. FIRESCPE-ACT, for example, has a detailed fire spread algorithm but a simplistic succession representation (fuel accumulation). FireBGCv2, on the other hand, has a detailed, physiologically based individual tree, vegetation dynamics simulation, but the fire spread algorithm is a simple cell percolation model (Table 1 ). Both model designs reflect compromises made by the model developers to create a model useful for exploring landscape dynamics for a particular ecosystem or for specific research objectives.

In this experiment, the use of succession cycle (SC) made it possible to standardize successional development across the disparate ecosystems, and it was estimated by each modeler before the simulations. As a result, some modelers underestimated this parameter (LANDSUM, FireBGCV2, LAMOS-HS; Table 1) and this could have influenced some of our conclusions.

The simulation design may also be somewhat flawed in that we allowed each modeler to simulate the ecosystem for which the model was developed rather than having all modelers simulate one ecosystem. It would have been difficult, if not impossible, to quantify parameters across all models for a common ecosystem 
because of the diversity of processes simulated by each model. The FIRESCAPE models, for example, would have needed fuel accumulation rates and FireBGCv2 would have needed an extensive set of ecophysiological parameters that probably would not have been unavailable for the selected ecosystem. As a result, our simulation results have an additional uncertainty that is related to differences across the ecosystems simulated rather than models used.

Another important limitation to this experiment is the selection of 10 successional stages to quantify successional development. We selected 10 successional classes as the best compromise to match the resolution of successional development across all landscape models. However, a lower number of classes would probably have reduced AVC simulation values (Table 3), resulting in completely different results with fire more important to landscape dynamics. It would have been difficult to standardize AVC values across the SC because vegetation development in most models isn't linear; some models (FireBGCv2, LAMOS) simulate succession dynamics as the complex interactions of vegetation and climate, while others (FIRESCAPE) simulate fuel accumulation from climate. There are few successional classifications that can be applied consistently across all ecosystems of the world and few standardized ways of classifying successional stages. Therefore, our results can only be interpreted in the context of 10 successional classes, and while the absolute values of AVC and VCR may appear arbitrary, we feel the trends in these numbers are what are really important, especially those trends under warming climates.

\section{Conclusions}

Our study supports the important role of wildland fire and vegetation succession in landscape dynamics. Landscapes of the world are shifting mosaics of successional communities created or maintained by disturbance regimes through complex interactions and feedbacks between fire, vegetation, fuel, and climate. While this study employed a set of disparate models (simple to complex) implemented on diverse landscapes (eucalypts to buttongrass to lodgepole) under different three climates, the overall trends were the same; fire and vegetation together change about $2-10 \%$ of the landscape per year and this change is greater under warmer, drier climates. Results from this study show the importance of interactions and feedbacks of ecological processes in governing landscape dynamics and ecosystem models must represent these interactions in their design to realistically simulate future conditions. Simulations with landscape fire succession models, such as we have done here, provide a unique opportunity to examine these relationships and how they may respond to changing climates.

We also conclude that there is no simple method of determining whether disturbance or succession has more influence on landscape dynamics because landscape behavior is uniquely dependent on disturbance history, biophysical context, and climate. Landscapes with histories of frequent and widespread fires may develop unique communities that are incredibly stable and resistant to successional change, such as the Tasmanian landscape, while areas with longer fire return intervals may have landscape change dominated by successional processes, such as the Yellowstone landscape (Grime, 1979; Connell and Slayter, 1977; Turner and Dale, 1998). And, the biophysical characteristics of the landscape dictate the rate at which communities develop and the characteristics of the fire regime, and their interactions. Also, the rate of vegetation change is somewhat dependent on the classification system used to describe successional development; attributes that change rapidly and nonuniformly over time, such as fuelbed loadings (FIRESCAPE-ACT) will generate higher succession change rates than attributes that change uniformly and slowly, such as species composition (LANDSUM, FireBGCv2) or age since disturbance (FIRESCAPE-SWTAS.
Results from this comparative simulation experiment emphasize the importance of including both succession and disturbance into coarse-scale vegetation modeling. DGVMs should simulate interactions of vegetation development with wildland fire to fully account for all biophysical feedbacks in landscape dynamics that govern future trajectories, and this is especially true if simulations are of future climates. Representing vegetation on a pixel as a constant PFT, for example, ignores the multiple pathways of successional development under changing climate and fire regimes. While the relative importance of fire and vegetation change appears to vary across ecosystems and landscapes, both processes change landscape composition and structure enough to significantly influence coarse-scale simulations. Moreover, the magnitudes of these changes appear to be significantly amplified under future climate warming. In summary, we suggest that landscape to regional to global simulations of vegetation-fire-climate dynamics include both vegetation succession and wildland fire to accurately predict effects of future climates and fire management on vegetation. Possible simulation approaches for integrating succession into coarse-scale models include (1) developing seral plant functional types (PFTs) that develop over time and in response to disturbance, (2) explicitly simulating a vegetation-fuel attribute that relates to fire and other disturbances, and (3) simulating the proportion of each pixel that is represented by each succession class (e.g., seral PFTs, fuel types).

\section{Acknowledgments}

We thank the Australian National University, National Science Foundation funded Wildfire-PIRE project, Joint Fire Science Program, and National Center for Ecological Analysis and Synthesis for support. We also thank Scott Stephens, Department of Environmental Science, Policy, and Management University of California, Berkeley for help designing the simulation experiment; Lisa Holsinger US Forest Service Rocky Mountain Research Station, for statistical analysis; and two anonymous reviewers for their insightful comments.

\section{References}

Agee, J.K., 1991. Fire history of Douglas-fir forests in the Pacific Northwest. In: Gen. Tech. Rept. PNW-GTR-285. USDA Forest Service, Pacific Northwest Research Station, Portland, Oregon.

Agee, J.K., 1993. Fire Ecology of Pacific Northwest Forests. Island Press, Washington DC, USA.

Anderson, D.G., Catchpole, E.A., DeMestre, N.J., Parkes, E., 1982. Modeling the spread of grass fires. Journal of the Australian Mathematical Society 23, 451-466.

Arora, V.K., Boer, G.J., 2005. Fire as an interactive component of dynamic vegetation models. Journal of Geophysical Research: Biogeosciences 110, G02008.

Bachelet, D., Lenihan, J.M., Daly, C., Neilson, R.P., 2000. Interactions between fire, grazing and climate change at Wind Cave National Park, SD. Ecological Modelling $134,229-244$

Baker, W.L., 1989. A review of models of landscape change. Landscape Ecology 2, 111-133.

Bazzaz, F.A., 1979. The physiological ecology of plant succession. Annual Review of Ecology \& Systematics 10, 351-371

Bowman, D.M.J.S., Balch, J.K., Artaxo, P., Bond, W.J., Carlson, J.M., Cochrane, M.A D’Antonio, C.M., DeFries, R.S., Doyle, J.C., Harrison, S.P., Johnston, F.H., Keeley, J.E., Krawchuk, M.A., Kull, C.A., Marston, J.B., Moritz, M.A., Prentice, I.C., Roos, C.I., Scott, A.C., Swetnam, T.W., van der Werf, G.R., Pyne, S.J., 2009. Fire in the earth system. Science 324, 481-484.

Bradstock, R.A., Cary, G.J., Davies, I., Lindenmayer, D.B., Price, O.F., 2012. Wildfires, fuel treatment and risk mitigation in Australian eucalypt forests: insights from landscape-scale simulation. Journal of Environmental Management 105, 66-75.

Cary, G., Flannigan, M.D., Keane, R.E., Bradstock, R., Davies, I.D., Lenihan, J.L., Li, C., Logan, K., Parsons, R., 2009. Relative importance of fuel management, ignition likelihood, and weather to area burned: evidence from five landscape fire succession models. International Journal of Wildland Fire 18, 147-156.

Cary, G.J., 2002. Importance of a changing climate for fire regimes in Australia. In: Bradstock, R.A., Gill, A.M., Williams, J.E. (Eds.), Flammable Australia: The Fire Regimes and Biodiversity of a Continent. Cambridge University Press, Cambridge, UK, pp. 26-46.

Cary, G.J., 1998. Predicting Fire Regimes and their Ecological Effects in Spatially Complex Landscapes. Australian National University, Canberra, AU, Doctoral thesis. 
Cary, G.J., Banks, J.C.G., 2000. Fire regime sensitivity to global climate change: an Australia perspective. In: Innes, J.L., Beniston, M., Verstraete, M.M. (Eds.), Biomass Burning and its Inter-relationships with the Climate System. Advances in Global Change Research, Vol. 3. Kluwer Academic Publishers, London, UK, pp. 233-246.

Cary, G.J., Keane, R.E., Gardner, R.H., Lavorel, S., Flannigan, M.D., Davies, I.D., Li, C., Lenihan, J.M., Rupp, T.S., Mouillot, F., 2006. Comparison of the sensitivity of landscape-fire-succession models to variation in terrain, fuel pattern and climate. Landscape Ecology 21, 121-137.

Catchpole, W., Bradstock, R., Choate, J., Fogarty, L., Gellie, N., McCarthy, G., McCaw, L., Marsden-Smedley, J., Pearce, G., 1998. Cooperative development of equations for heathland fire behaviour. In: Viegas, D.X. (Ed.), Proc. 3rd Int. Conf. on Forest Fire Research/14th Fire and Forest Meteorology Conf., Luso, $16 \pm 20$ November 1998. ADAI, University of Coimbra, Coimbra, pp. 631-645.

Cheney, N.P., Gould,J.S., Catchpole, W.R., 1998. Prediction of fire spread in grasslands. International Journal of Wildland Fire 8 (1), 1-3.

Clark, J.S., 1993. Fire, climate change, and forest processes during the past 2000 years. Geological Society of America, Special Paper 276, 295-308.

Clements, F., 1916. Plant Succession: An Analysis of the Development of Vegetation. Carnegie Institution of Washington, Washington DC.

Connell, J.H., Slayter, R.O., 1977. Mechanisms of succession and their role in community stabilization and organization. American Naturalist 111, 1119-1144.

Conroy, R.J., 1996. To burn or not burn? A description of the history, nature and management of bushfires within Ku-Ring-Gai Chase National Park. Proceedings of the Linnean Society of New South Wales 116, 80-96.

Crutzen, P.J., Goldammer, J.G., 1993. Fire in the Environment: The Ecological, Atmospheric and Climatic Importance of Vegetation Fires. John Wiley and Sons, New York, NY, USA.

Dale, V.H., Rauscher, H.M., 1994. Assessing impacts of climate change on forests: the state of biological modeling. Climatic Change 28, 65-90.

DeBano, L.F., Neary, D.G., Ffolliott, P.F., 1998. Fire's Effect on Ecosystems. John Wiley and Sons, New York, New York USA.

Flannigan, M.D., Amiro, B.D., Logan, K.A., Stocks, B.J., Wotton, B.M., 2005. Forest fires and climate change in the 21st century. Mitigation and Adaptation Strategies for Global Change 11, 847-859.

Fosberg, M.A., Cramer, W., Brovkin, V., Fleming, R., Gill, A.M., Goldammer, J.G., Keane, R., Koehler, P., Lenihan, J., Neilson, R., Sitch, S., Thornicke, K., Venevski, S., Weber, M.G., Wittenberg, U., 1999. Strategy for a fire module in dynamic global vegetation models. International Journal of Wildland Fire 9, 79-84

Fox, B., Fox, M., Mckay, G., 1979. Litter accumulation after fire in a Eucalypt forest. Australian Journal of Botany 27, 157-165.

Gardner, R.H., Romme, W.H., Turner, M.G., 1999. Predicting forest fire effects at landscape scales. In: Mladenoff, D.J., Baker, W.L. (Eds.), Spatial Modeling of Forest Landscape Change: Approaches and Applications. Cambridge University Press, Cambridge, United Kingdom, pp. 163-185.

Girod, C.M., Hurtt, G.C., Frolking, S., Aber, J.D., King, A.W., 2007. The tension between fire risk and carbon storage: evaluating US carbon and fire management strategies through ecosystem models. Earth Interactions 11, 1-31.

Grime, J.P., 1979. Plant Strategies and Vegetation Processes. Wiley, New York, NY, USA.

Holsinger, L., Keane, R.E., Steele, B., Reeves, M.C., Pratt, S., 2006. Using historical simulations of vegetation to assess departure of current vegetation conditions across large landscapes. In: Rollings, M.G., Frame, C. (Eds.), The LANDFIRE Prototype Project: Nationally Consistent and Locally Relevant Geospatial Data for Wildland Fire Management. USDA Forest Service Rocky Mountain Research Station, pp. 315-367.

He, H.S., 2008. Forest landscape models, definition, characterization, and classification. Forest Ecology and Management 254, 484-498.

IPCC, 2007. Climate Change 2007 - the Physical Science Basis. Cambridge University Press, New York, NY, USA, 427 pp.

Iverson, L.R., Prasad, A.M., 2002. Potential redistribution of tree species habitat under five climate change scenarios in the eastern US. Forest Ecology and Management 155, 205-222.

Jackson, W.D., 1968. Fire, air, water and earth - an elemental ecology of Tasmania. Proceedings of the Ecological Society of Australia 3, 9-16.

Keane, R.E., Cary, G., Davies, I.D., Flannigan, M., Gardner, R.H., Lavorel, S., Lenihan, J.M., Li, C., Rupp, T.S., 2007. Understanding global fire dynamics by classifying and comparing spatial models of vegetation and fire dynamics. In: Canell, J., Patalki, L., Patalki, P. (Eds.), Terrestrial Ecosystems in a Changing World - GCTE Synthesis Book. Cambridge University Press, Cambridge, United Kindom.

Keane, R.E., Cary, G., Davies, I.D., Flannigan, M.D., Gardner, R.H., Lavorel, S., Lennihan, J.M., Li, C., Rupp, T.S., 2004. A classification of landscape fire succession models: spatially explicit models of fire and vegetation dynamic. Ecological Modelling 256, 3-27.

Keane, R.E., Finney, M.A., 2003. The simulation of landscape fire, climate, and ecosystem dynamics. In: Veblen, T.T., Baker, W.L., Montenegro, G., Swetnam, T.W. (Eds.), Fire and Global Change in Temperate Ecosystems of the Western Americas. Springer-Verlag, New York, New York, USA, pp. 32-68.

Keane, R.E., Garner, J., Teske, C., Stewart, C., Paul, H., 2002a. Range and variation in landscape patch dynamics: implications for ecosystem management. In: Proceedings from the 1999 National Silviculture Workshop, USDA Forest Service Rocky Mountain Research Station, Kalispell, MT USA, pp. 19-26.

Keane, R.E., Holsinger, L., Pratt, S., 2006. Simulating historical landscape dynamics using the landscape fire succession model LANDSUM version 4.0. In: General Technical Report RMRS-GTR-171CD. USDA Forest Service Rocky Mountain Research Station, Fort Collins, CO USA.
Keane, R.E., Loehman, R.A., Holsinger, L.M., 2011. The FireBGCv2 landscape fire and succession model: a research simulation platform for exploring fire and vegetation dynamics. In: General Technical Report RMRS-GTR-255. U.S. Department of Agriculture, Forest Service, Rocky Mountain Research Station, Fort Collins, CO USA.

Keane, R.E., Morgan, P., Running, S.W., 1996. FIRE-BGC - A Mechanistic Ecological Process Model for Simulating Fire Succession on Coniferous Forest Landscapes of the Northern Rocky Mountains. United States Department of Agriculture, Forest Service Intermountain Forest and Range Experiment Station, Ogden, UT USA, Research Paper INT-RP-484

Keane, R.E., Parsons, R., Hessburg, P., 2002b. Estimating historical range and variation of landscape patch dynamics: limitations of the simulation approach. Ecological Modelling 151, 29-49.

Keane, R.E., Arno, S.F., Brown, J.K., 1989. FIRESUM - an ecological process model for fire succession in western conifer forests. In: General Technical Report INT-266. USDA Forest Service.

King, K., Cary, G., Bradstock, R., Chapman, J., Pyrke, A., Marsden-Smedlay, J., 2006. Simulation of prescribed burning strategies in south-west Tasmania, Australia: effects on unplanned fires, fire regimes, and ecological management values. International Journal of Wildland Fire 15, 527-540.

King, K.J., Bradstock, R.A., Cary, G.J., Chapman, J., Marsden-Smedley, J.B., 2008. The relative importance of fine scale fuel mosaics on reducing fire risk in south west Tasmania, Australia. International Journal of Wildland Fire 17, 421-430.

King, K.J., de Ligt, R.M., Cary, G.J., 2011. Fire and carbon dynamics under climate change in south-eastern Australia: insights from FullCAM and FIRESCAPE modelling. International Journal of Wildland Fire 20, 563-577.

Krawchuk, M.A., Moritz, M.A., Parisien, M.-A., Van Dorn, J., Hayhoe, K., 2009. Global pyrogeography: the current and future distribution of wildfire. PLoS ONE 4, e5102.

Kuleshov, Y., de Hoedt, G., Wright, W., Brewster, A., 2002. Thunderstorm distribution and frequency in Australia National Climate Centre, Bureau of Meteorology, Melbourne. Australian Meteorological Magazine 51, 145-154.

Lauenroth, W.K., Canham, C.D., Kinzig, A.P., Poiani, K.A., Kemp, W.M., Running, S.W., 1998. Simulation modeling in ecosystem science. In: Pace, M.L., Groffman, P.M. (Eds.), Successes, Limitations, and Frontiers in Ecosystem Science. SpringerVerlag, New York, New York, USA, pp. 404-415.

Lauenroth, W.K., Urban, D.L., Coffin, D.P., Parton, W.J., Shugart, H.H., Kirchner, T.B. Smith, T.M., 1993. Modeling vegetation structure-ecosystem process interactions across sites and ecosystems. Ecological Modelling 67, 49-80.

Lavorel, S., Davies, I.D., Noble, I.R., 2000. LAMOS: a LAndscape MOdelling shell. In: Landscape Fire Modeling-Challenges and Opportunities. Natural Resources Canada. Canadian Forest Service, Vancouver, BC, Canada, pp. 25-28.

Lenihan, J.M., Daly, C., Bachelet, D., Neilson, R.P., 1998. Simulating broad scale fire severity in a dynamic global vegetation model. Northwest Science 72, 91-103.

Li, C., Hans, H., Barclay, H., Liu, J., Carlson, G., Campbell, D., 2008. Comparison of spatially explicit forest landscape fire disturbance models. Forest Ecology and Management 254, 499-510.

Loehle, C., LeBlanc, D., 1996. Model-based assessments of climate change effects on forests: a critical review. Ecological Modelling 90, 1-31.

Marsden-Smedley, J.B., Catchpole, W.R., 1995a. Fire behaviour modelling in Tasmanian buttongrass moorlands. I. Fuel characteristics. International Journal of Wildland Fire 5, 203-214

Marsden-Smedley, J.B., Catchpole, W.R., 1995b. Fire behaviour modelling in Tasmanian buttongrass moorlands. II. Fire behaviour. International Journal of Wildland Fire 5, 215-228.

Marsden-Smedley, J.B., Catchpole, W.R., 2001. Fire modelling in Tasmanian buttongrass moorlands. III. Dead fuel moisture. International Journal of Wildland Fire 10, 241-253

Marsden-Smedley, J.B., Rudman, T., Pyrke, A., Catchpole, W.R., 1999. Buttongrass moorland fire-behaviour prediction and management. Tasforests 11 , 87-107.

Marsden-Smedley, J.B., Catchpole, W.R., Pyrke, A., 2001. Fire modelling in Tasmanian buttongrass moorlands. IV. Sustaining versus non-sustaining fires. International Journal of Wildland Fire 10, 255-262.

McArthur, A.G., 1967. Fire behavior in eucalypt forests. In: Leaflet Number 107. Commonwealth of Australia Forestry and Timber Bureau.

McCarthy, M.A., Cary, G.J., 2002. Fire regimes in landscapes: models and realities. In: Bradstock, R.A., Williams, J., Malcom Gill, A. (Eds.), Flammable Australia: the Fire Regimes and Biodiversity of a Continent. Cambridge University Press, Cambridge, United Kingdom, pp. 77-94.

McKenzie, D., 1998. Fire, vegetation, and scale: toward optimal models for the Pacific Northwest. Northwest Science 72, 49-65.

McKenzie, D., Peterson, D.L., Alvarado, E., 1996. Predicting the Effect of Fire on LargeScale Vegetation Patterns in North America - Abstract Research Paper. USDA Forest Service Pacific Northwest Research Station.

Mladenoff, D.J., Baker, W.L., 1999. Spatial Modeling of Forest Landscape Change. Cambridge University Press, Cambridge, United Kingdom.

Moore, A.D., Noble, I.R., 1990. An individualistic model of vegetation stand dynamics. Journal of Environmental Management 31, 611

Neilson, R.P., Pitelka, L.F., Solomon, A.M., Nathan, R.J., Midgeley, G.F., Fragoso, J.M., Lischke, H., Thompson, K., 2005. Forecasting regional to global plant migration in response to climate change. Bioscience 55, 749-760.

Neilson, R.P., Running, S.W., 1996. Global Dynamic Vegetation Modelling: Coupling Biogeochemistry and Biogeography Models. Pages 451-465 Global Change and Terrestrial Ecosystems. Cambridge University Press, New York, New York, USA. 
Noble, I.R., Barry, G.A.V., Gill, A.M., 1980. McArthur fire-danger meters expressed as equations. Australian Journal of Ecology 5, 20-103.

Olson, J., 1981. Carbon balance in relation to fire regimes. In: Mooney, H.A., Bonnicksen, T.M., Christensen, N.L., Lotan, J.E., Reiners (Technical Coordinators), W.A. (Eds.), Proceedings of the Conference Fire Regimes and Ecosystem Properties. USDA Forest Service, pp. 327-378.

Olson, J., 1963. Energy storage and the balance of the producers and decomposers in ecological systems. Ecology 44, 322-331.

Perry, G.L.W., Millington, J.D.A., 2008. Spatial modelling of succession-disturbance dynamics in forest ecosystems: concepts and examples. Perspectives in Plant Ecology, Evolution and Systematics 9, 191-210.

Pfeiffer, M., Spessa, A., Kaplan, J.O., 2013. A model for global biomass burning in preindustrial time: LPJ-LMfire (v1.0). Geoscientific Model Development 6, 643-685, http://dx.doi.org/10.5194/gmd-6-643-2013.

Prentice, I.C., Monserud, R.A., Smith, T.M., Emanuel, W.R., 1993. Modeling largescale vegetation dynamics. In: Solomon, A.M., Shugart, H.H. (Eds.), Vegetation Dynamics \& Global Change. Chapman \& Hall, New York, New York, USA, pp. 235-250.

Raison, R.J., Woods, P.V., Khanna, P.K., 1983. Dynamics of fine fuels in recurrently burnt eucalypt forests. Australian Forestry 46, 294-302.

Reinhardt, E., Keane, R.E., Brown, J.K., 1997. First Order Fire Effects Model: FOFEM 4.0 User's Guide. General Technical Report INT-GTR-344. USDA Forest Service.

Roderick, M.L., Rotstayn, L.D., Farquhar, G.D., Hobbins, M.T., 2007. On the attribution of changing pan evaporation. Geophysical Research Letters 34, L17403, http://dx.doi.org/10.1029/12007GL031166.

Rothermel, R.C., 1972. A Mathematical Model for Predicting Fire Spread in Wildland Fuels. US Forest Service Intermountain Research Station Research Paper INT115, Ogden, Utah, pp. 40.

Rothermel, R.C., 1983. How to Predict the Spread and Intensity of Forest and Range Fires. General Technical Report INT-143. United States Department of Agriculture Forest Service, Ogdon, UT.

Rotstayn, L.D., Roderick, M.L., Farquhar, G.D., 2006. A simple pan-evaporation model for analysis of climate simulations: evaluation over Australia. Geophysical Research Letters 33, L17715, http://dx.doi.org/10.1029/2006GL027114.

Running, S.W., Hunt Jr., E.R., 1993. Generalization of a Forest Ecosystem Process Model for other Biomes, BIOME-BGC, and an Application for Global-Scale Models. Pages 141-157 Scaling Physiological Processes: Leaf to Globe. Academic Press, Inc.

Running, S.W., Nemani, R.R., 1991. Regional hydrologic and carbon balance responses of forests resulting from potential climate change. Climatic Change 19, 349-368.

Scheller, R., Mladenoff, D., 2007. An ecological classification of forest landscape simulation models: tools and strategies for understanding broad-scale forested ecosystems. Landscape Ecology 22, 491-505.
Schmidt, K.M., Menakis, J.P., Hardy, C.C., Hann, W.J., Bunnell, D.L., 2002. Development of Coarse-Scale Spatial Data for Wildland Fire and Fuel Management. General Technical Report RMRS-GTR-87. USDA Forest Service Rocky Mountain Research Station, Fort Collins, CO, USA.

Schoennagel, T.L., Veblen, T.T., Romme, W.H., 2004. The interaction of fire, fuels, and climate across Rocky Mountain landscapes. Bioscience 54, 651-672.

Seidl, R., Fernandes, P.M., Fonseca, T.F., Gillet, F., Jönsson, A.M., Merganicová, K., Netherer, S., Arpaci, A., Bontemps, J.-D., Bugmann, H., González-Olabarria, J.R. Lasch, P., Meredieu, C., Moreira, F., Schelhaas, M.-J., Mohren, F., 2011. Modelling natural disturbances in forest ecosystems: a review. Ecological Modelling 222, 903-924.

Spies, T.A., Lindenmayer, D.B., Gill, A.M., Stephens, S.L., Agee, J.K., 2012. Challenges and a checklist for biodiversity conservation in fire-prone forests: perspectives from the Pacific Northwest of USA and Southeastern Australia. Biological Conservation $145,5-14$.

Swetnam, T.W., 1990. Fire history and climate in the southwestern United States. In: Effects of Fire Management of Southwestern Natural Resources: Proceedings of the Symposium. USDA Forest Service, Rocky Mountain Forest and Range Experiment Station, Fort Collins, CO, USA, pp. 293.

Swetnam, T.W., Baisan, C.H., 1996. Historical fire regime patterns in the soutwestern United States since AD 1700. In: Fire Effects in Southwestern Forests, Proceeding of the 2nd La Mesa Fire Symposium. Rocky Mountain Forest and Range Experiment Station, Forest Service, USDA, pp. 11-32.

Thonicke, K., Venevski, S., Sitch, S., Cramer, W., 2001. The role of fire disturbance for global vegetation dynamics: coupling fire into a Dynamic Global Vegetation Model. Global Ecology and Biogeography Letters 10, 661-678.

Turner, M.G., Dale, V.H., 1998. Comparing large, infrequent disturbances: what have we learned? Ecosystems 1, 493-496.

Urban, D.L., Bonan, G.B., Smith, T.M., Shugart, H.H., 1991. Spatial applications of GAP models. Forest Ecology and Management 42, 95-110.

Vivian, L.M., Cary, G.J., Bradstock, R.A., 2008. Influence of fire severity on the regeneration, recruitment and distribution of eucalypts in the Cotter River Catchment, Australian Capital Territory. Austral Ecology 33, 55-67.

Walker, J., 1981. In: Gill, A.M., Groves, R.H., Noble, I.R. (Eds.), Fuel Dynamics in Australian Vegetation. Fire and the Australian Biota. Australian Academy of Science, Canberra, pp. 101-127.

Waring, R.H., Running, S.W., 1998. Forest Ecosystems: Analysis at Multiple Scales, Second ed. Academic Press, Inc, San Diego, CA., USA.

Weber, M.G., Flannigan, M.D., 1997. Canadian boreal forest ecosystem structure and function in a changing climate: impact on fire regimes. Environmental Review $5,145-166$. 